REALA, número 14, octubre-marzo de 2020

Sección: ARTÍCULOS

Recibido: 10-08-2020

Modificado: 15-09-2020

Aceptado: 15-09-2020

DOI: https://doi.org/10.24965/reala.i14.10851

Páginas: 6-28

\title{
La presunción de validez de los actos administrativos ${ }^{1}$
}

\section{The presumption of validity of administrative acts}

\author{
Tomás Cano Campos \\ Universidad Complutense de Madrid (España) \\ ORCID: https:/ /orcid.org/0000-0003-2268-9681 \\ tcano@der.ucm.es
}

\section{NOTA BIOGRÁFICA}

Catedrático de Derecho Administrativo de la Universidad Complutense de Madrid. Sus líneas de investigación se centran en la invalidez de los actos y de las normas, las sanciones administrativas, los contratos públicos, la responsabilidad patrimonial de la Administración, el tráfico, los transportes y la movilidad.

\section{RESUMEN}

La presunción de validez de los actos administrativos está expresamente recogida en nuestro ordenamiento jurídico y es habitualmente utilizada en el razonamiento práctico y teórico de los juristas. Pero es una figura cuestionada, pues no sólo se discute su naturaleza de verdadera presunción, sino también el fundamento en que se apoya y su propia utilidad o función. En el presente trabajo, tras realizar una serie de precisiones conceptuales y analizar su naturaleza jurídica, destaco que el fundamento de la presunción de validez reside en razones institucionales ligadas a la estabilización de expectativas y de situaciones jurídicas, por lo que desempeña una importante función al servicio de la seguridad jurídica y del funcionamiento eficaz del sistema, y defiendo que tiene una mayor capacidad explicativa, analítica e, incluso, directiva que otros conceptos que se han propuesto en su lugar, por lo que tiene una clara utilidad en la construcción de una teoría del acto administrativo.

\section{PALABRAS CLAVE}

Actos administrativos; ejecutividad; presunciones; validez; presunción de validez.

\begin{abstract}
The presumption of validity of administrative acts is expressly included in our legal order and is usually used in the practical and theoretical reasoning of jurists. But it is a questioned legal concept, since not only is its nature of legal presumption discussed, but also the foundation on which it rests and its own usefulness or function. In the present paper, after making a series of conceptual analysis and studying its legal nature, I emphasize that the foundation of the legal presumption of validity resides in institutional reasons linked to the stabilization of expectations and legal situations, which is why it plays an important role in service of legal certainty and the effective operation of the system. I also defend that it has a greater explanatory, analytical and even directive capacity than other legal concepts that have been proposed in its place, for which it has a clear utility framing a general administrative legal act theory.
\end{abstract}

\section{KEYWORDS}

Administrative legal acts; enforcement; presumptions; validity; presumption of validity.

1 Grupo de Investigación "Las transformaciones del Estado y la autonomía Local: organización institucional, servicios públicos y democracia participativa", de la Universidad Complutense de Madrid. He realizado una primera aproximación al tema, mucho más sintética, en el Tratado de Procedimiento Administrativo Común y Régimen Jurídico del Sector público, dirigido en 2017 por E. Gamero Casado, y en el libro homenaje al profesor José Luis Carro Fernández-Valmayor, coordinado, también en 2017, por Luís Míguez Macho y Marcos Almeida Cerrada. 


\section{SUMARIO}

1. INTRODUCCIÓN. 2. EXISTENCIA. 3. EFICACIA. 4. EJECUTIVIDAD. 5. VALIDEZ. 6. PRESUNCIÓN DE VALIDEZ: ¿VERDADERA PRESUNCIÓN? 7. LAS NORMAS DE PRESUNCIÓN. 8. FUNDAMENTO Y FUNCIÓN DE LA PRESUNCIÓN DE VALIDEZ. 9. EFECTOS DE LA PRESUNCIÓN. 10. ÁMBITO OBJETIVO DE LA PRESUNCIÓN: SU APLICACIÓN A TODOS LOS ACTOS ADMINISTRATIVOS. 11. PRESUNCIÓN DE VALIDEZ Y ¿PRESUNCIÓN DE LEGALIDAD? 12. CONCLUSIONES. BIBLIOGRAFÍA CITADA.

\section{INTRODUCCIÓN}

El art. 39.1 de la Ley 39/2015, de 1 de octubre, de Procedimiento Administrativo Común de las Administraciones Públicas (LPAC), en términos idénticos al art. 57.1 de la Ley 30/1992, dispone que: «Los actos de las Administraciones Públicas sujetos al Derecho Administrativo se presumirán válidos y producirán efectos desde la fecha en que se dicten». La presunción de validez de los actos administrativos, además de en este precepto, esta consagrada también con carácter general, aunque con otro nombre, en la propia Ley 7/1985, de 2 de abril, reguladora de las Bases del Régimen Local, cuyo art. 4.1.e) reconoce expresamente a los municipios, las provincias y las islas «la presunción de legitimidad y la ejecutoriedad de sus actos».

La presunción de validez, según parece, tendría su origen en el Derecho regio intermedio, donde se mantenía la praesumtio pro se de las decisiones del príncipe, y de ahí habría pasado a formar parte, ya con el constitucionalismo, de la denominada autotutela de la Administración ${ }^{2}$.

Se trata de una figura utilizada habitualmente por la Administración, por los jueces y por los juristas en sus razonamientos prácticos y teóricos. Pero es una categoría discutida, pues no sólo se ha puesto en duda su naturaleza de verdadera presunción, lo que es una cuestión menor, sino también el fundamento en que se apoya y su propia utilidad o función en el sistema normativo. Algunos autores la han cuestionado frontalmente porque la consideran por completo innecesaria y entienden que los efectos que se le atribuyen derivarían ya de otras categorías existentes, como la ejecutividad de los actos administrativos ${ }^{3}$. Pero otros, por el contrario, la han ensalzado con especial entusiasmo y lucidez destacando su importancia y funcionalidad ${ }^{4}$.

En el presente trabajo, sostengo la diferencia conceptual entre la presunción de validez de los actos administrativos y su ejecutividad, su conexión causal y la utilidad de ambas figuras en la teoría del acto administrativo. Para ello realizaré, en primer lugar, una serie de precisiones conceptuales previas, como la fijación del hecho jurídico o institucional a partir del cual se presume la validez (la existencia del acto), la cualidad o cualificación jurídica que se presume (su validez o adecuación a Derecho), así como la eficacia del acto y su ejecutividad, las cuales derivan realmente de la existencia del acto y no de su validez, pero se ven claramente reforzadas con la presunción. Tras ello, analizaré la naturaleza jurídica de la presunción de validez, cuál es su fundamento y su función en el ordenamiento, qué significado y efectos tiene y cuál es su ámbito de aplicación. Por último, trataré de justificar por qué no me parece necesario distinguir entre una presunción de validez y otra de legalidad y ofreceré unas conclusiones para terminar.

\section{EXISTENCIA}

El art. 39 de la LPAC, al disponer que los actos administrativos «se presumirán válidos y producirán efectos desde la fecha en que se dicten», contempla distintos aspectos de los actos, lo que requiere su diferenciación conceptual.

\footnotetext{
2 Sobre sus orígenes, J. L. VILLAR PALASí (2001): Técnicas remotas del Derecho Administrativo, Madrid, INAP, págs. 27-30; J. L. VILLAR PALASí y J. L. VILLAR EZCURRA (1999): Principios de Derecho Administrativo, Tomo II, Madrid, Servicio de publicaciones de la UCM, págs. 148-149. Vid. también, con más matices y otros posibles orígenes históricos, R. LETELIER WARTENBERG (2011): Nulidad y restablecimiento en procesos contra normas, Cizur Menor, Civitas Thomson Reuters, págs. 238-243.

3 Hacen una crítica frontal, R. LETELIER WARTENBERG (2011: 254-258); D. MARÍN-BARNUEVO FABO (2018): "Presunciones legales, disposiciones supletorias y verdades interinas. La presunción de validez de los actos administrativos”, en M. VAQUER CABALLERÍA, A. M. MORENO MOLINA y A. DESCALZO GONZÁLEZ (coords.), Estudios de Derecho público en homenaje a Luciano Parejo Alfonso, tomo II, Valencia, Tirant lo Blanch, págs. 1.273-1.301.

4 La ha defendido en un profundo, meticuloso y sugestivo estudio, cuyas tesis centrales comparto, M. REBOLLO PUIG (2005): "La presunción de validez", en REDA, núm. 128, págs. 587-638.
} 
Un primer aspecto, previo a todos los demás, es el momento en que el acto es dictado por la Administración, momento a partir del cual el acto adquiere existencia (jurídica). A partir de ese momento, el acto se presume válido o conforme a Derecho (aunque puede realmente no serlo), debe ser acatado por todos y produce efectos jurídicos (aunque puede no producirlos para sus destinatarios, por ejemplo, si está sometido a una condición suspensiva o es precisa su notificación). A ese primer aspecto, esto es, al simple hecho de que el acto haya sido dictado por la Administración, se le puede denominar existencia ${ }^{5}$. Puede afirmarse, en cierto modo, que la existencia del acto no es propiamente un predicado, pues el existir algo no es una cualidad de nada, sino el presupuesto o condición previa de todas las cualidades de ese algo (de su eficacia, de su validez, de su ejecutividad, etc. $)^{6}$.

La existencia del acto administrativo no depende de la concurrencia de todos los denominados elementos del acto (que, en rigor, son requisitos de validez), sino sólo de la presencia de algunos de ellos. Pero el Derecho positivo, como también ocurre en el caso de las normas, no establece expresamente cuáles son las condiciones necesarias y suficientes para la existencia del acto (lo que algunos denominan su validez constitutiva), esto es, aquellos requisitos mínimos que hacen que el acto pueda ser reconocido como tal, de modo que, generalmente, será preciso el pronunciamiento autoritativo (esto es, vinculante o investido de autoridad) de algún órgano competente para que deje de contar como tal acto y no produzca los efectos que al dictarlo pretende la Administración ${ }^{7}$.

Por eso, las precisiones quizá no puedan ir más allá de considerar que estaremos en presencia de un acto administrativo cuando una declaración o decisión de un caso concreto se pueda imputar a una Administración. Se pueden poner algunos ejemplos (extravagantes) en que esos requisitos mínimos no se dan y, por tanto, no hará falta el referido pronunciamiento, pero nada más. Por ejemplo, una orden de derribo impuesta por un particular, una concesión demanial otorgada por un grupo de estudiantes en una clase práctica o una sanción privativa de libertad impuesta por un alcalde. Pero, en estos casos, estaremos ante un no-acto, ante algo que no es nada para el Derecho. No estaremos ante ningún resultado institucional (porque el particular o los estudiantes no tienen conferido el poder de dictar actos administrativos ni un alcalde el de imponer una sanción tal, por lo que no se puede imputar a la Administración), sino ante una acción natural. Se trata de algo que, ni siquiera prima facie, aparece como una instancia de aquello que pretende ser: un acto administrativo.

Sin embargo, cuando esa apariencia mínima de acto si se da (por ejemplo, hay una falsificación de la orden o de la concesión o el alcalde impone de plano otro tipo de sanción), ya no podremos considerar que no se trata de un acto administrativo. A ello coadyuva el propio poder de que goza la Administración para ejecutar forzosamente sus decisiones, de modo que toda decisión capaz de producir cualquier tipo de efecto que la Administración pueda imponer forzosamente debe considerarse acto administrativo y su destinatario no podrá limitarse a desconocerlo sin más. De ahí que, numerosos autores consideren la figura de la inexis-

\footnotetext{
5 Hay autores que hablan de perfección del acto, pero en un sentido distinto al de existencia, reflejado en el texto, pues afirman que un acto es perfecto cuando ha sido dictado por el órgano competente y con arreglo al procedimiento establecido o cuando en su producción concurren todos sus elementos esenciales. Vid. J. A. GARCÍA-TREVIJANO FOS (1991): Los actos administrativos, Madrid, Civitas, pág. 333; R. BOCANEGRA SIERRA (2012): Lecciones sobre el acto administrativo, Cizur Menor, Civitas Thomson Reuters, pág. 122; R. PARADA VÁZQUEZ (2017): Derecho Administrativo II. Régimen jurídico de la actividad administrativa, Madrid, Dykinson, pág. 66; F. GARRIDO FALLA (1994): Tratado de Derecho Administrativo, tomo I, 12. ${ }^{a}$ ed., Madrid, Tecnos, que identifica perfección con validez (pág. 497). Pero la competencia del órgano que dicta el acto y su aprobación con arreglo al procedimiento legalmente establecido son, realmente, requisitos para su validez. Por ello, un acto dictado por un órgano incompetente o prescindiendo del procedimiento legalmente establecido podrá ser considerado inválido, de modo que, precisamente porque goza de presunción de validez, su destinatario o la Administración podrán reaccionar contra él con los instrumentos previstos para ello por el ordenamiento, pero no podrá decirse, ni tales sujetos considerar, que el acto no existe.

6 Solo de normas o actos que, de algún modo, han llegado a existir, o bien hablando de ellos en términos hipotéticos, se podrá predicar algo. Cfr. J. R. CAPELLA (1999): Elementos del análisis jurídico, Madrid, Trotta, pág. 85; M. ATIENZA RODRÍGUEZ y J. RUIZ MANERO (2003): "Seis acotaciones para una teoría de la validez jurídica", Doxa, núm. 26, señalan, en la misma línea, que el planteamiento de cuestiones como la validez presupone la existencia del resultado institucional de que se trate (una ley, una sentencia, un contrato, un acto, etc.), pág. 727.

7 R. GUASTINI (2010): Le fonti del Diritto. Fondamenti teorici, Milano, Giuffrè, dice, por eso, que no es posible trazar una línea clara de demarcación entre invalidez e inexistencia: los dos conceptos, por así decir, se difuminan o desvanecen el uno en el otro (pág. 264). El límite entre lo irrelevante jurídicamente (lo inexistente como acto) y lo inválido, pero existente, depende de creencias, prácticas, etc., que es imposible reconstruir con precisión. Se trata de la tensión, difícil de eliminar, entre la dimensión fáctica del Derecho visto como fenómeno social y el Derecho visto como un sistema de normas que disciplina su propia creación. Vid. M. ATIENZA RODRÍGUEZ y J. RUIZ MANERO (2003: 726); A. RÓDENAS CALATAYUD (2009): "Los enredos de la validez: tres distinciones para no perderse", en Teoría del Derecho. Revista de pensamiento jurídico, núm. 6, pág. 178.
} 
tencia de escasa utilidad en nuestro ordenamiento jurídico-administrativo ${ }^{8}$. Aunque otros no la descartan para casos evidentes y groseros como los señalados, en los que puede afirmarse que no hay realmente un acto administrativo, y cuyo régimen sería el que la teoría clásica y el Derecho Administrativo de otros países atribuyen a la nulidad de pleno derecho: el acto inexistente no gozaría de presunción de validez y no sería obligatorio, por lo que podría ser desconocido por cualquiera y no sería susceptible de ejecución forzosa ${ }^{9}$.

\section{EFICACIA}

La manifestación primaria de la existencia del acto administrativo es su eficacia y ejecutividad. La existencia, y no la validez, es ya condición suficiente para que el acto sea ejecutivo y eficaz.

La eficacia es la capacidad de los actos (o de las normas) para producir efectos jurídicos. Por ejemplo, se habla de eficacia retroactiva de una norma o de un acto para referirse a la capacidad para producir efectos con relación a situaciones o supuestos producidos con anterioridad a su entrada en vigor o a la emanación del acto; se dice que la notificación es condición de eficacia del acto para significar que un acto no produce efectos jurídicos para sus destinatarios (en particular si le perjudican) antes de que aquélla se produzca; se afirma que la eficacia de la ley es distinta a la de los actos o los contratos porque aquélla es productora de efectos erga omnes, mientras que éstos sólo son idóneos para producir efectos inter partes.

Un acto administrativo es eficaz cuando produce los efectos jurídicos que le son propios, lo cual depende de su contenido: la calificación normativa de una conducta como obligatoria, permitida o prohibida; la atribución, el reconocimiento o negación de una calificación institucional a una clase de personas (por ejemplo, a los afectados por una sequía, un terremoto o una pandemia), a un objeto (por ejemplo, su calificación como bien mueble) o a un estado de cosas (por ejemplo, la declaración de zona catastrófica); etc. Pero el acto no sólo produce efectos respecto de sus destinatarios, sino también en relación a la propia Administración que lo ha dictado, a otras Administraciones y a cualquier tercero que de algún modo pueda verse afectado ${ }^{10}$.

La eficacia jurídica pertenece a un mundo convencional e institucional como es el Derecho, no al mundo físico o de la realidad ${ }^{11}$. La eficacia del acto no son los efectos de hecho que produce en la realidad, sino los efectos de Derecho, el cambio jurídico que origina en función de su contenido ${ }^{12}$. Por ello, la eficacia jurídica

8 J. A. SANTAMARÍA PASTOR (1975): La nulidad de pleno derecho de los actos administrativos. Contribución a una teoría de la ineficacia en el Derecho público, 2. ${ }^{a}$ ed., Madrid, IEA, pág. 207; C. CHINCHILLA MARÍN (1993): "Nulidad y anulabilidad", en J. LEGUINA VILLA y M. SÁNCHEZ MORÓN (dirs.): La nueva Ley de Régimen Jurídico de las Administraciones Públicas y del Procedimiento Administrativo Común, Madrid, Tecnos, pág. 194; M. BELADIEZ ROJO (1994b): "La nulidad y la anulabilidad. Su alcance y significación”, en RAP, núm. 133, 1994, págs. 155 y ss.; J. GARCÍA LUENGO (2002): La nulidad de pleno derecho de los actos administrativos, Madrid, Civitas, págs. 78 y ss.; G. DOMÉNECH PASCUAL (2002): La invalidez de los reglamentos, Valencia, Tirant lo Blanch, págs. 201 y ss.

9 M. REBOLLO PUIG (2018): "La invalidez del acto administrativo", en M. REBOLLO PUIG y D. VERA JURADO (dirs.): Derecho Administrativo, tomo II, 3. ${ }^{a}$ ed., Madrid, Tecnos, pág. 116. Vid. también S. MUÑOZ MACHADO (2017): Tratado de Derecho Administrativo y Derecho público General. Tomo XII. Actos administrativos y sanciones administrativas, 2. ${ }^{a}$ ed., Madrid, BOE, pág. 84 . El Código Europeo de Contratos, conocido coloquialmente como Anteproyecto de Pavía, recoge, junto a la nulidad y la anulabilidad, la inexistencia del contrato, que tiene lugar, según dispone su art. 137.1, cuando «un hecho, un acto, una declaración o situación es reconocible externamente pero no identificable socialmente como un contrato», y que, según precisa el art. 138, «determina la ausencia total de cualquier efecto en el ámbito contractual», por lo que «cualquier interesado puede actuar como si no existiese el contrato en cualquier momento, sin que haya plazo de prescripción».

10 R. BOCANEGRA SIERRA (2012: 126-127). Algunos autores, siguiendo a la doctrina alemana, distinguen entre una eficacia externa (inmediata o formal) y una eficacia interna (práctica o mediata). La eficacia externa sería el conjunto de consecuencias adjetivas o formales (el acto con eficacia externa puede constituir la resolución de un procedimiento, es susceptible de impugnación y puede ser objeto de conversión) que se producen a partir del momento en que se dicta el acto y no necesariamente con su notificación. Mientras que la eficacia interna aludiría la vigencia de la regulación que el acto incorpora, a la producción de efectos o consecuencias que derivan del contenido del acto. Vid. J. A. GARCíA-TREVIJANO FOS, J. A. (1991: 334); F. VELASCO CABALLERO (1996): Las cláusulas accesorias del acto administrativo, Madrid, Tecnos, pág. 85; R. BOCANEGRA SIERRA (2011): "La distinción entre la eficacia interna y la eficacia externa de los actos administrativos", REDA, núm. 152, págs. 778-779.

11 A. NIETO GARCÍA (1994): "Estudio preliminar", al libro de M. BELADIEZ ROJO: Validez y eficacia de los actos administrativos, Madrid, Marcial Pons, pág. 20; R. BOCANEGRA SIERRA (2012: 126); J. GARCÍA LUENGO (2002: 249). En la teoría del Derecho, entre otros, R. GUASTINI (1999) Distinguiendo. Estudios de teoría y metateoría del Derecho (traducción de J. FERRER I BELTRÁN), Barcelona, Gedisa, pág. 321; L. PRIETO SANCHÍS (2005), Apuntes de Teoría del Derecho, Madrid, Trotta, págs. 83-85; L. FERRAJOLI (2011), Principia luris. Teoría del derecho y de la democracia. 1. Teoría del derecho, Madrid, Trotta, págs. 251, 268. Consideran, por el contrario, que la eficacia es un dato empírico J. A. SANTAMARÍA PASTOR (1975: 159-161 y 175); J. L. VILLAR PALASÍ y J. L. VILLAR EZCURRA (1999: 154); y, de forma insistente, V. S. BACA ONETO (2006): La invalidez de los contratos, Cizur Menor, Thomson Civitas, págs. $44-45,55,77,79$.

12 En rigor, la eficacia jurídica de una norma es distinta de su eficacia fáctica o real. Comúnmente, se llama «efectiva» a una norma que es generalmente obedecida (cumplida, si establece mandatos; observada, si establece prohibiciones). Vid. R. GUASTINI 
se produce con independencia de la subsiguiente acción u omisión de otros actos que sean actuaciones de dichos efectos, las cuales no siempre son precisas o necesarias. Así, la eficacia de una orden de demolición, es la obligación de demoler (no la efectiva destrucción del edificio); la de una multa, la obligación de pagarla (no la efectiva realización del pago); la de una licencia de caza o edificación, el derecho a cazar o a edificar (no la realización de la actividad cinegética o la efectiva construcción del edificio). Si la eficacia jurídica se moviera en el terreno de los hechos, no cabría hablar, por ejemplo, de una eficacia retroactiva de los actos administrativos como hace el art. 39.3 LPAC, pues lo que ocurre en el terreno de la realidad no puede retrotraerse en el tiempo (el pasado no es modificable materialmente). Lo que sí puede ocurrir, y a eso es a lo que realmente alude la eficacia retroactiva, es que se tomen en consideración hechos ya acaecidos para atribuirles, desde ahora y en adelante, determinados efectos jurídicos, es decir, que las normas o los actos realicen una valoración jurídica de hechos del pasado y les atribuyan determinadas consecuencias jurídicas para el futuro.

Pero, aunque por eficacia jurídica se entienda una modificación o cambio jurídico cualquiera, es lo cierto que al hablar de efectos se piensa de inmediato en los resultados prácticos o materiales que constituyen el objetivo o resultado final al que tienden los sujetos de Derecho. Ello es inevitable ya que, aunque la eficacia jurídica pertenece al plano estrictamente jurídico, trata de proyectarse sobre la realidad, pues para eso se aprueba una norma, se dicta un acto o se celebra un contrato. Así, por ejemplo, en la licencia de obras lo que interesa es la construcción del edificio, en una orden de desalojo de un local la salida efectiva de quienes se hallan en su interior, en la sanción pecuniaria el pago de la multa por el responsable de la infracción, etc. Por eso, uno de los significados que los juristas atribuyen al término eficacia alude, precisamente, a la consecución de los fines o resultados pretendidos en el terreno de los hechos. Así, en el discurso sociológico jurídico, y también en contextos de teoría general del Derecho, se dice que una norma o un acto son «eficaces» cuando son efectivamente usados, observados o aplicados o cuando alcanza el resultado o la finalidad pretendida. En estos contextos, una norma o un acto puede ser más o menos cumplido u observado, esto es, su cumplimiento admite gradaciones porque se puede medir empíricamente.

Pero, por lo general, en el lenguaje jurídico el término «eficacia», predicado de los actos o de las normas, alude a sus efectos o consecuencias jurídicas, por lo que para aludir a la materialización de tales efectos parece más correcto utilizar el término «efectividad» o hablar de eficacia fáctica o real o, simplemente, de mutación de la realidad, lo cual puede tener lugar bien porque el particular cumple voluntariamente el acto, bien porque la Administración lo ejecuta forzosamente ${ }^{13}$. En cualquier caso, como se precisará de inmediato, hay actos administrativos que no requieren de materialización alguna y, por tanto, no necesitan ser cumplidos por su destinatario ni pueden ser ejecutados por la Administración.

\section{EJECUTIVIDAD}

La ejecutividad es la cualidad de los actos administrativos para producir sus efectos jurídicos de forma imperativa, vinculante e inmediata. Es la forma de ser de la eficacia de los actos administrativos. El acto administrativo, al gozar de ese atributo de la ejecutividad, tiene per se fuerza obligatoria o vinculante, de modo que todos los sujetos a los que afecte deben actuar conforme a lo que dispone su contenido al declarar el Derecho en el caso concreto. En definitiva, la ejecutividad supone que el acto debe ser generalmente observado, acatado y obedecido.

En ocasiones, se afirma que la ejecutividad supone la obligatoriedad de cumplimiento inmediato del acto por parte de sus destinatarios so pena de ser ejecutados por la propia Administración ${ }^{14}$. Pero hay que tener en cuenta que, sin perjuicio de ese carácter vinculante del acto para todos los sujetos a los que pueda afec-

(2016): La sintaxis del Derecho, Madrid, Marcial Pons, pág. 121. Como también señala L. PAREJO ALFONSO (2020): "La actuación administrativa a caballo de la división entre normación y simple ejecución y el caso de la planificación y el plan", en Revista de Derecho Público: Teoría y Método, núm. 1, «a las normas jurídicas es inherente la pretensión de efectividad o, lo que es lo mismo, de hacerse realidad», por lo que «precisan ser seguidas de un conjunto de actividades dirigidas derechamente a ajustar aquella realidad a sus proposiciones» (pág. 5).

13 Habla de efectividad, L. FERRAJOLI (2011: 426-427).

14 S. MUÑOZ MACHADO (2017: 75). El Diccionario del Español Jurídico define la ejecutividad como la propiedad de los actos administrativos que implica su capacidad para producir efectos y la obligación de ser acatados por sus destinatarios desde el momento en que se dictan, salvo en los supuestos en que la ley permite la suspensión de su eficacia, pudiendo la propia Administración exigir su ejecución. 
tar, la exigencia de cumplimiento inmediato del acto por el interesado, bajo la amenaza de ejecución forzosa por la Administración, sólo concurre realmente en los actos administrativos que le imponen una obligación, pero no en los que le reconocen u otorgan un derecho (cuya eficacia consiste en la facultad de ejercerlo), en los de carácter constitutivo (que tampoco precisan por parte de su destinatario de ningún acto de aplicación), o en aquellos en los que la obligación se impone a la propia Administración (reconocimiento de un trienio, otorgamiento de una ayuda o subvención). En estos casos, la obligada es la propia Administración, que debe abstenerse de obstruir el ejercicio del derecho o, en su caso, debe realizar los actos de aplicación que exige el contenido del acto sin necesidad de un incumplimiento previo (que ni existe ni puede existir) por parte de su destinatario.

En los actos de carácter constitutivo, una vez dictados, ni siquiera es preciso que la Administración realice algo más, pues producen por sí solos los resultados finales a los que tienden. Por ejemplo, la nacionalización de una persona, la inscripción en el Padrón municipal o la jubilación de un funcionario, en los que, para conseguir el resultado pretendido (la adquisición de la nacionalidad, la condición de vecino o la pérdida de la condición de funcionario), no es preciso que la Administración realice algo más, ya que surten efectos y éstos se materializan desde el momento de su emisión/notificación.

La ejecutividad de los actos administrativos se prevé, con carácter general, en el art. 38 de la LPAC, a tenor del cual los «actos de las Administraciones Públicas serán ejecutivos con arreglo a lo dispuesto en esta Ley», así como en el art. 98 que, con el rubro de ejecutoriedad, dispone que: «Los actos de las Administraciones Públicas serán inmediatamente ejecutivos, salvo que: a) Se produzca la suspensión de la ejecución del acto. b) Se trate de una resolución de un procedimiento de naturaleza sancionadora...». Es una manifestación del poder de autotutela (declarativa) de la Administración, en virtud de la cual puede, sin el auxilio de los Tribunales, declarar, crear, modificar o extinguir de forma unilateral e imperativa situaciones jurídicas subjetivas (derechos, obligaciones, deberes, cargas, permisos, etc.).

La ejecutoriedad alude, en realidad, a la posibilidad de ejecución forzosa por parte de la Administración, pero, como se acaba de ver, no todos los actos administrativos son susceptibles de ejecución forzosa porque no todos tienen un contenido obligacional. Por eso, como se ha dicho expresivamente, «la autotutela ejecutiva no es la continuación natural e insoslayable de la autotutela declarativa» ${ }^{15}$.

\section{VALIDEZ}

Mientras que para que un acto administrativo exista, y sea eficaz, es preciso únicamente que sea dictado de conformidad con algunas de las normas que regulan su producción (que pueda imputarse a una Administración, que se exteriorice de algún modo), para que sea válido es preciso, además, que se adecue a todas las normas que regulan su emanación y condicionan su contenido, salvo a aquellas de tipo formal cuya infracción da lugar a las denominadas irregularidades no invalidantes. Por lo tanto, existencia y validez son categorías diferentes.

La validez también es distinta de la eficacia y de la ejecutividad. Primero, porque, como se adelantó, condición suficiente de eficacia de un acto no es su validez, sino su existencia y, generalmente, su notificación. El ordenamiento dispone que si no concurre ninguna causa de demora de la eficacia (art. 39.1 y 2 LPAC), el acto sea eficaz desde el momento en que se dicta, aunque no sea válido o conforme a Derecho. Segundo, porque el acto puede ser válido (cumple todos los requisitos formales y materiales de validez que exige el ordenamiento) pero ineficaz porque concurra alguna causa de demora de la eficacia. Tercero, porque, como veremos, en virtud de la presunción de validez, hasta que un órgano competente para ello no declare su invalidez, el acto y los efectos jurídicos que ha desplegado, sigue desplegando o va a desplegar gozan del respaldo del Derecho por muchos vicios o irregularidades invalidantes que presente y por muy graves que éstas sean. Se produce así, una escisión entre validez y eficacia, que da lugar a que puedan producirse (y materializarse) efectos jurídicos no conformes a Derecho. Los efectos producidos y eventualmente materializados por un acto que incurre en irregularidades invalidantes no son jurídicamente protegibles, pero hasta su anulación el acto es jurídicamente eficaz por imposición del propio ordenamiento. Parte del enredo y confusión que hay en torno a la invalidez de los actos administrativos y sus consecuencias creo

15 J. BARCELONA LLOP (2017): “La ejecución forzosa de los actos administrativos: régimen general. La prohibición de acciones posesorias", en E. GAMERO CASADO (dir.), Tratado de Procedimiento Administrativo Común y Régimen Jurídico Básico del Sector Público, tomo II, Valencia, Tirant Lo Blanch, pág. 2.232. 
que se debe a que no se tienen en cuenta estos dos momentos temporales y a que no se precisa en cuál de ellos se sitúa el discurso.

La validez es un concepto comparativo, es un juicio de relación entre un resultado institucional (en nuestro caso, un acto administrativo, pero también una norma, un contrato, una sentencia, etc.) y las normas que regulan su producción. Como es sabido, las acciones y los resultados institucionales son aquellos que no son posibles en ausencia de reglas constitutivas, es decir, de reglas que crean la posibilidad de dichas acciones y resultados. Así, por ejemplo, mientras que acciones y resultados como matar y estar muerto son posibles en ausencia de normas, y el concepto no depende de regla alguna, acciones como aprobar una ley, celebrar un contrato o dictar una sentencia o un acto y sus correspondientes resultados (ley, contrato, sentencia, acto jurídico) solo son posibles de acuerdo con reglas del referido tipo, en concreto de las reglas constitutivas que confieren poderes (lo que conocemos como normas de competencia) ${ }^{16}$. Por eso, en el ámbito jurídico, la validez es una cualidad que se puede predicar de distintas acciones y resultados institucionales: de las normas, de los actos jurídicos que las aplican (actos administrativos, actos procesales, etc.), de los actos de autonomía privada (contratos, testamentos, donaciones, etc.) o de cláusulas particulares de tales actos (cláusulas contractuales, testamentarias, accesorias, etc.) ${ }^{17}$.

El Derecho establece que un resultado institucional es válido cuando reúne los requisitos establecidos por las normas que regulan su producción y determinan su contenido. Se habla de validez formal cuando el acto se ha dictado de conformidad con (algunas de) las normas que regulan su producción y, más concretamente, cuando ha sido dictado por el órgano competente, siguiendo el procedimiento establecido y en la forma requerida. Se habla de validez material cuando la norma es compatible con las normas del sistema que limitan su contenido ${ }^{18}$. Por tanto, un acto administrativo es válido en la medida en que haya sido dictado de conformidad con las normas que regulan su producción y predeterminan su contenido. Aunque el acto también es válido cuando infringe determinadas normas que regulan su producción, pero el ordenamiento califica la irregularidad como no invalidante. A tales requisitos alude el art. 34 de la LPAC (dentro del capítulo dedicado a los requisitos de los actos administrativos), cuando establece que los actos que dicten las Administraciones Públicas se deben producir por el órgano competente, ajustándose al procedimiento establecido y con un contenido determinado y adecuado a lo dispuesto por el ordenamiento jurídico.

Desde el punto de vista de la teoría de las normas, las reglas que regulan la emanación de los actos administrativos no sólo son normas constitutivas, secundarias o que confieren poderes (normas de competencia, según una terminología más próxima a nosotros), sino también normas regulativas, primarias o deónticas (las que establecen obligaciones, prohibiciones o permisos), que disponen como han de ser usados los poderes conferidos a la Administración. Tales normas establecen y regulan los casos en los que procede actuar la potestad en cuyo ejercicio se dicta el acto, el procedimiento que ha de seguirse para ello, la finalidad que debe perseguirse, la forma en que se puede exteriorizar, etc., de modo que un uso de tales potestades vulnerando estas normas no determina la inexistencia o no consecución del acto como resultado institucional, sino su irregularidad y, eventualmente, su invalide $z^{19}$.

Estas normas sobre la producción de los actos administrativos, que establecen sus requisitos de vali$\mathrm{dez}$, son las que regulan o se refieren a los tradicionalmente conocidos como elementos del acto ${ }^{20}$. Pero, en realidad, los denominados elementos del acto son, en su mayor parte, requisitos para su validez ${ }^{21}$. Ni siquie-

16 Vid. M. ATIENZA RODRÍGUEZ y J. RUIZ MANERO (2003: 719); J. A. PÉREZ LLEDÓ (2015): "Normas constitutivas: reglas que confieren poderes, reglas puramente constitutivas. Las definiciones", en D. GONZÁLEZ LAGIER (coord.), Conceptos básicos del derecho, Madrid, Marcial Pons, págs. 28 y ss.

17 Vid. R. GUASTINI (1999): Distinguiendo. Estudios de teoría y metateoría del Derecho (traducción de J. FERRER I BELTRÁN), Barcelona, Gedisa, pág. 319. Un esquema ordenado de todo aquello que puede ser calificado como válido o inválido, en M. ATIENZA RODRÍGUEZ y J. RUIZ MANERO (2003: 722).

18 Pero la validez formal no se corresponde con la existencia o validez constitutiva ni la validez material con la validez regulativa. Vid. A. RÓDENAS CALATAYUD (2009: 183); R. GUASTINI (2010: 256-258).

19 Cfr. M. ATIENZA RODRÍGUEZ y J. RUIZ MANERO (2003: 725). Sustancialmente coincidente, R. GUASTINI (1999: 324 y ss.). Sobre las normas constitutivas o que confieren poderes, vid. M. ATIENZA RODRÍGUEZ y J. RUIZ MANERO (2007): Las piezas del

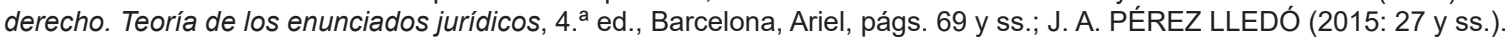

20 Como señaló S. CASSESE (1995): Le basi del diritto amministrativo, 3. ${ }^{a}$ ed., Torino, Garanti, «un poco por no haber vinculado hasta el fondo el acto administrativo con la función y la organización, un poco por la influencia ejercida por la dogmática privatista, que analiza una realidad hecha por personas físicas, el capítulo del Derecho administrativo relativo a los elementos de los actos administrativos está lleno de expresiones antropomórficas, como voluntad, vicio...» (pág. 336). En el mismo sentido, R. BOCANEGRA SIERRA (2012: 80).

21 En este sentido, A. GALLEGO ANABITARTE y A. MENÉNDEZ REXACH (2001): Acto y procedimiento administrativo, Madrid, Marcial Pons, págs. 195 y ss.; J. GARCÍA LUENGO J. (2002: 96); R. BOCANEGRA SIERRA (2011: 80) y (2012: 80); R. LETELIER 
ra forman parte estructural del acto, sino que se contemplan en la norma que confiere el poder en virtud del cual el acto se dicta o en otras normas del sistema que determinan la Administración y el órgano competente, el procedimiento a seguir, el presupuesto de hecho, el fin, etc. ${ }^{22}$.

La LPAC se ocupa de tales requisitos en los arts. 34 a 36, pero el ordenamiento se centra, sobre todo, en su ausencia o infracción (arts. 47 y 48 LPAC) y en los instrumentos técnicos para declarar la invalidez que resulta de tales infracciones (arts. 106 a 110 LPAC; arts. 25 y ss. LJCA, etc.), ya que, en un sistema institucionalizado como el Derecho, la última palabra sobre la validez o invalidez de un acto (o una norma, o una sentencia, etc.) la tienen, con carácter imperativo, determinados órganos del Estado. Tales requisitos de validez, como ya se ha anticipado, pueden ser de tipo formal (validez formal) o de tipo material (validez material) ${ }^{23}$.

Cuando falta uno de los requisitos que dan lugar a la invalidez del acto, pero ésta ya no se puede declarar (por ejemplo, porque el acto no se haya recurrido en plazo o ya no se pueda revisar de oficio al operar los límites de la revisión), el acto no es por ello válido o conforme a Derecho, como tampoco lo es cuando el propio ordenamiento proteja y mantenga sus efectos, a pesar de que incurra en vicios de nulidad o de anulabilidad. En el primer caso, el paso del tiempo no hace válido lo inválido, lícito lo ilícito o regular lo irregular, como tampoco cabe pensar que el tiempo prive al acreedor de su condición de tal o convierta el asesinato en una acción lícita; y, sin embargo, el crédito y la acción para perseguir el delito están sujetos a la disciplina del tiempo, es decir, a plazos de prescripción ${ }^{24}$. Frente a lo que a veces se afirma, el transcurso del tiempo no sana o convalida la irregularidad, sino que hace que ésta deje de ser relevante para el Derecho. La irregularidad subsistirá, pero por razones de seguridad jurídica ya será tarde para discutir si existe o no y la situación creada por el acto ya no podrá removerse. La firmeza de un acto no implica necesariamente su validez.

En el segundo supuesto, el que se mantengan los efectos de un acto incluso declarado inválido es la consecuencia que el Derecho anuda a otros principios del sistema. Pero tales principios no se erigen en canon de validez del acto, por lo que éste no puede considerarse conforme a Derecho. Si consideráramos que, en estos casos, el acto es válido, no se explicaría por qué en ocasiones los efectos que se mantienen no son los mismos que los que se derivan del propio acto (por ejemplo, en las expropiaciones declaradas nulas, una indemnización superior al justiprecio por la privación de la propiedad) ${ }^{25}$. Además, con esa forma de entender la validez no se formula juicio alguno de reproche a la Administración cuando vulnera la legalidad a la que está sujeta. Y el concepto de validez se esfuma o difumina en el de eficacia.

\section{PRESUNCIÓN DE VALIDEZ: ¿VERDADERA PRESUNCIÓN?}

Aclarados (o estipulados) tales conceptos, cuya conexión se irá viendo a lo largo de este estudio, y centrándonos ya en la presunción de validez, lo primero que conviene precisar es que el art. 39.1 de la LPAC no recoge una presunción en el sentido procesal del término, por lo que se pueden hacer las mismas precisiones conceptuales que he hecho respecto de otra «presunción» como la de certeza o veracidad de las actas de inspección y de las denuncias de los agentes de la autoridad ${ }^{26}$.

En virtud de las presunciones, como es sabido, se tiene por acreditado un hecho (hecho presunto) a partir de la prueba o fijación formal como cierto de otro hecho (el indicio o base), y ello sobre la base de un

WARTENBERG (2011: 70); S. MUÑOZ MACHADO (2017: 43); G. FERNÁNDEZ FARRERES (2018): Sistema de Derecho Administrati-

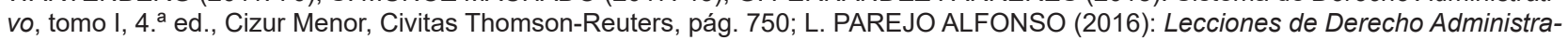
tivo, 8. ${ }^{a}$ ed., Valencia, Tirant lo Blanch, págs. 506 y 530.

22 Vid., por ejemplo, E. GARCÍA DE ENTERRÍA y T. R. FERNÁNDEZ RODRÍGUEZ (2017): Curso de Derecho Administrativo, I, 18. ${ }^{a}$ ed., Cizur Menor, Civitas Thomson Reuters, págs. 597 y ss.; L. COSCULLUELA MONTANER (2019): Manual de Derecho administrativo, 30. ${ }^{a}$ ed., Cizur Menor, Civitas Thomson Reuters, págs. 374-375.

23 R. BOCANEGRA SIERRA (2012: 81 y ss.); H. MAURER (2011): Derecho Administrativo. Parte general, Madrid, Marcial Pons, cit., pág. 266, que anteponen como requisito previo de validez la admisibilidad de la actuación administrativa mediante actos administrativos.

24 M. PAQUAU LIAÑO (2007): "La acción de nulidad sí prescribe", en J. DELGADO ECHEVERRÍA (coord.), Las nulidades de los contratos: un sistema en evolución, Cizur Menor, Thomson Aranzadi, pág. 233.

25 Me he ocupado de ello en T. CANO CAMPOS (2017): "El laberinto de la invalidez: algunas pistas para no perderse", en InDret 4/2017, y (2018): “Consideraciones generales sobre la invalidez en el Derecho Administrativo", en Documentación Administrativa, Nueva Época, núm. 5, enero-diciembre 2018, págs. 7-26.

26 Vid. T. CANO CAMPOS (2008): Presunciones y valoración legal de la prueba en el Derecho administrativo sancionador, Cizur Menor, Civitas, págs. 27-40 
juicio de probabilidad, regularidad o normalidad, fruto de la experiencia, que hace que produciéndose el primer hecho se considere altamente probable que también se dé el segundo ${ }^{27}$. Cuando el enlace o conexión entre el hecho base y el hecho presunto lo lleva a cabo el juez, sobre la base de tales juicios o máximas de experiencia, se habla de presunciones judiciales (o presunciones hominis), mientras que si es la ley la que lo estipula se habla de presunciones legales (o presunciones iuris) ${ }^{28}$. Son ejemplos de estas últimas la presunción de paternidad prevista en el art. 116 del CC o la de residencia habitual en territorio español que prevé el art. 9.1.b) de la Ley 35/2006, de 28 de noviembre del Impuesto sobre la Renta de las Personas Físicas.

En este concepto (procesal) de presunción, hecho base y hecho presunto son dos hechos distintos, deduciéndose este último de la prueba o acreditación del primero. Las presunciones, así entendidas, permiten, por ello, probar la existencia de un hecho de forma mediata y, según la doctrina procesalista, no suponen una inversión de la carga de la prueba (onus probandi), sino, a lo sumo, una alteración de lo que hay que probar (thema probandi), pues la parte beneficiada por la presunción no se ve exonerada de la prueba ya que tendrá que acreditar, como mínimo, el hecho base o indicio.

Es evidente que la presunción de validez no es una presunción en este sentido, pues el art. 39.1 LPAC no se basa en un hecho a partir de cuya prueba o fijación formal la ley obligue a tener por cierto otro hecho distinto ${ }^{29}$. Por la sencilla razón de que, en la presunción de validez de los actos, no hay dos hechos diferentes, sino, si acaso, un único hecho: el hecho de que la Administración ha dictado un acto administrativo. En rigor, no hay un hecho base natural sino, institucional pues la obligación que surge de la presunción de validez (actuar como si el acto fuera conforme a Derecho hasta que se declare su invalidez) no depende de la prueba de ningún hecho natural, sino, más simplemente, de la circunstancia de que se haya dictado un acto administrativo, que es un hecho institucional ${ }^{30}$. Por otra parte, la validez que se presume no es un hecho nuevo, sino un predicado o cualidad, con un determinado valor jurídico, de ese acto dictado por la Administración ${ }^{31}$.

La presunción de validez de los actos administrativos tampoco constituye una ficción como han sostenido algunos autores ${ }^{32}$. Las ficciones consisten en considerar acaecido un hecho cuando se sabe con certeza que no es así, al objeto de aplicarle el mismo régimen jurídico de otro hecho o fenómeno claramente distinto ${ }^{33}$. El significado del término ficción en el Diccionario de la Lengua y en el del Español Jurídico avala tam-

27 El Diccionario del Español Jurídico define la presunción como la aceptación de un hecho del que no se tiene prueba y que se infiere de otro hecho demostrado. En la doctrina, vid. A. DE LA OLIVA SANTOS e I. DIEZ-PICAZO GIMÉNEZ (2004): Derecho procesal civil. El proceso de declaración, 3. ${ }^{a}$ ed., Madrid, Ceura, págs. 417-419, que definen las presunciones como «las operaciones intelectuales, imperadas o autorizadas por el Derecho positivo o consentidas por el buen sentido de un hombre experimentado, que consisten en tener por cierto un hecho (el hecho presunto) a partir de la fijación formal como cierto de otro hecho (el indicio o base)»; J. MONTERO AROCA (2007), La prueba en el proceso civil, 5. a ed., Madrid, Civitas, 2007, para quien las presunciones constituyen «un razonamiento en virtud del cual, partiendo de un hecho que está probado, se llega a la consecuencia de la existencia de otro hecho, que es el supuesto fáctico de una norma, atendiendo al nexo lógico existente entre los dos hechos» (pág. 181). La doctrina mayoritaria considera que las presunciones no son un medio de prueba, sino una operación o mecanismo de fijación de los hechos. Vid., además de los anteriores, M. SERRA DOMíNGUEZ (1981): "De las presunciones", en M. ALBALADEJO (dir.), Comentarios al Código Civil y compilaciones forales, tomo XVI, vol. 2, Madrid, Edersa, 1981, pág. 571.

28 Vid. los arts. 385 y 386 LEC.

29 En el mismo sentido, M. REBOLLO PUIG (2005: 592); G. DOMÉNECH PASCUAL (2010): "El principio de presunción de validez", en J. A. SANTAMARÍA PASTOR (dir.): Los principios jurídicos del Derecho Administrativo, Madrid, La Ley, pág. 1.032; R. LETELIER WARTENBERG (2011: 252).

30 Los hechos son los eventos que acaecen en el mundo. Son naturales los que ocurren con independencia de las normas (cumplir 18 años de edad, la muerte de una persona, etc.) y son institucionales los que dependen de las normas, que, como vimos, se denominan constitutivas porque constituyen tales hechos o acciones institucionales (alcanzar la mayoría de edad, la sucesión de derechos por el fallecimiento, una compraventa, dictar una sentencia o un acto, aprobar una norma). Sobre el tema, D. GONZÁLEZ LAGIER (2015): "Hechos y acciones en el Derecho", en D. GONZÁLEZ LAGIER (coord.), Conceptos básicos del derecho, Madrid, Marcial Pons, págs. 65-67, de quien tomo el concepto y los ejemplos. Como él mismo precisa, hay un concepto amplio de hecho que engloba estados de cosas, sucesos, acciones, omisiones, etc., pero los juristas, a veces, utilizan una noción más estricta y contraponen hechos y acciones, para significar que éstas dependen de la voluntad humana mientras que aquellos no (pág. 66).

31 Los procesalistas consideran que no estamos en presencia de una verdadera presunción cuando de un hecho no se deduce otro distinto, sino una consecuencia jurídica. Vid., por ejemplo, A. DE LA OLIVA e I. DIEZ-PICAZO GIMÉNEZ (2004: 419); J. MONTERO $\operatorname{AROCA}(2007:$ 181).

32 D. BLANQUER CRIADO (2014): "Disgresiones sobre la invalidez de los actos administrativos", en J. E. SORIANO GARCÍA (dir.): Por el Derecho y la libertad. Libro homenaje al profesor Juan Alfonso Santamaría Pastor, volumen I, Madrid, lustel, págs. 1.286 y 1.294; J. M. TRAYTER JIMÉNEZ (2019): Derecho Administrativo. Parte General, 4. a ed., Barcelona, Atelier, pág. 360.

33 R. VON IHERING (1997): El espíritu del Derecho romano, Barcelona, Marcial Pons: «Puede, pues, llamarse a la ficción una mentira técnica consagrada por la necesidad» (pág. 311); J. BENTHAM (1981): Tratado de legislación civil y penal, Madrid, Editorial Nacional: «Entiendo por ficción un hecho notoriamente falso sobre el cual se razona como si fuera verdadero» (pág. 83). Vid. también 
bién esta idea ${ }^{34}$. La ficción no considera verdadero un hecho cualquiera, sino que considera acaecido algo que es falso, pero con una falsedad por completo evidente, manifiesta y asumida, de modo que no resulta engañosa ${ }^{35}$. El ejemplo clásico es el de la fictio legis Corneliae, que consideraba como muerto en combate al ciudadano romano que caía prisionero al objeto de que su testamento surtiera efectos, pues, como es sabido, el Derecho romano sólo concedía eficacia al testamento del hombre libre, cualidad que se perdía al ser apresado. Otro ejemplo es la ficción prevista en el art. 29 del CC, según el cual al concebido se le tiene por nacido para todos los efectos que le sean favorables.

En el Derecho administrativo, el ejemplo típico es el silencio administrativo, pues se considera que, a determinados efectos jurídicos, ha acaecido un hecho institucional (que la Administración ha contestado en sentido estimatorio o desestimatorio) cuando se sabe con certeza que no es así porque no ha dado respuesta alguna ${ }^{36}$. El carácter de ficción, tanto del silencio positivo como del negativo, no impide que el propio legislador diferencie luego entre ambos supuestos y considere, como hace, que en un caso la ficción de suponer que se ha contestado en sentido positivo constituye un acto presunto (mejor ficticio) finalizador del procedimiento a todos los efectos, mientras que en otro (silencio negativo) la ficción no crea acto administrativo alguno y tiene como principal efecto permitir al interesado la interposición en cualquier momento de los recursos procedentes.

En la presunción de validez no se parte de que el acto sea antijurídico e inválido pero se finge que es conforme a Derecho, sino de que, al margen de su conformidad o no al ordenamiento (que puede concurrir o no), hay que actuar como si el acto fuera válido (o sin plantearse siquiera si lo es o no) hasta que su invalidez sea declarada de forma autoritativa por los órganos competentes para ello.

\section{LAS NORMAS DE PRESUNCIÓN}

En cualquier caso, el término «presunción» es ambiguo en el lenguaje jurídico, ya que los juristas, y el propio legislador, no siempre lo utilizan con el mismo significado ni con el mismo propósito o función ${ }^{37}$. Así, junto a la concepción tradicional de las presunciones (o presunciones en sentido procesal, donde hay un hecho base, un hecho presumido y un enlace que se basa en un juicio de probabilidad o regularidad), también se habla, sobre todo en el ámbito de la teoría del Derecho, de normas de presunción para aludir a aquellas normas jurídicas que, para garantizar determinados bienes, intereses o valores, imponen por verdadera una situación o una calificación jurídica que puede admitir o no prueba en contrario ${ }^{38}$.

En las normas de presunción se incluyen, además de las presunciones legales o iuris a que se refiere el art. 385 LEC, presunciones que no lo son en el sentido procesal indicado (por eso, los procesalistas, y algunos otros autores, hablan de presunciones aparentes o falsas presunciones), como, por ejemplo, la presunción de inocencia, la de buena fe en la posesión o la de constitucionalidad de las leyes o de validez de los actos administrativos, las cuales no pretender describir o establecer una regularidad basada en la expe-

L. ROSENBERG (2002): La carga de la prueba, 2. ${ }^{a}$ ed., Montevideo, BdF, pág. 248; K. LARENZ (1994): Metodología de la Ciencia del Derecho (traducción de M. RODRÍGUEZ MOLINERO), Barcelona, Ariel, pág. 255.

34 El Diccionario del Español Jurídico define la ficción legal como «artificio jurídico que permite otorgar efectos jurídicos a una situación o relación inexistente, como si se hubiera producido».

35 D. MARÍN-BARNUEVO FABO (1996): Presunciones y técnicas presuntivas en Derecho Tributario, Madrid, McGraw-Hill, pág. 136; R. HERNÁNDEZ MARÍN (1998): Introducción a la teoría de la norma jurídica, Barcelona, Marcial Pons, pág. 289; L. ALARCÓN SOTOMAYOR (2007): El procedimiento administrativo sancionador y los derechos fundamentales, Cizur Menor, Civitas, págs. 342-343; M. GASCÓN ABELLÁN (2010): Los hechos en el Derecho, 3. a ed., Madrid, Marcial Pons, págs. 132-133.

36 F. GONZÁLEZ NAVARRO (2005): "Silencio administrativo", en S. MUÑOZ MACHADO (dir.): Diccionario de Derecho Administrativo, tomo II, Madrid, lustel, pág. 2.433; F. VELASCO CABALLERO (2017): "El acto administrativo: concepto, clases y contenido", en E. GAMERO CASADO (dir.), Tratado de procedimiento administrativo común y régimen jurídico básico del sector público, Valencia, Tirant lo Blanch, pág. 1.788.

37 Las presunciones, además, no sólo tienen un importante papel en el Derecho, sino también en la teoría de la argumentación, en la epistemología y en la pragmática, pues el razonamiento humano de carácter presuntivo precede a la noción jurídica de presunción. Sobre ello, J. RAMIA (2017): "La noción de presunción más allá del Derecho", en Revista de Humanidades, núm. 32, págs. 125-138.

38 Sobre el tema, J. AGUILÓ REGLA (2006): "Presunciones, verdad y normas procesales", Isegoría, núm. 35, págs. 16-18 y (2018): "Las presunciones en el Derecho", en Anuario de Filosofía del Derecho, núm. 34, págs. 215-219; M. GASCÓN ABELLÁN (2010: 125-130); D. MENDONCA (1998): "Presunciones", Doxa núm. 21, págs. 83 y ss. (recogido también en su libro Las claves del Derecho, Barcelona, Gedisa, 2000, págs. 215 y ss.). Un análisis actual de las presunciones en el Derecho, tanto en el continental como en el common law, en R. GAMA LEYVA (2019): Las presunciones en el Derecho. Entre la perplejidad y la fascinación de los juristas, Valencia, Tirant lo Blanch, para quien afirmar que todas las presunciones tienen un hecho base, un hecho presumido y un enlace basado en un juicio de probabilidad ofrece una imagen bastante reducida de las presunciones en el Derecho (pág. 65). 
riencia, sino que obedecen a razones garantistas o a razones vinculadas a la estabilización de expectativas y situaciones jurídicas que pretenden cumplir determinadas instituciones del sistema ${ }^{39}$.

No todas las normas de presunción comparten la misma estructura ni se basan o persiguen los mismos valores ${ }^{40}$. En algunas presunciones, como en la de inocencia o en la de conmoriencia (art. $33 \mathrm{CC}$ ) no se exige la previa prueba de ningún hecho base como condición para que puedan entrar a operar: en la primera, el acusado no debe probar nada para que se le considere inocente, pues basta que no exista prueba del hecho que se le imputa; $y$ en la segunda basta que no haya prueba del hecho controvertido para considerar que las dos personas murieron al mismo tiempo ${ }^{41}$. En otras, como en la propia presunción de inocencia, en la de veracidad de las actas de inspección o en la de validez de los actos administrativos tampoco hay, en rigor, un hecho presunto, sino más bien una cualidad jurídica predicable de una persona respecto de la comisión de unos hechos tipificados como delito o infracción, de un documento público o de un acto jurídico ${ }^{42}$. Por eso, algunos autores definen a las normas de presunción, en términos más amplios, como normas jurídicas que obligan a reconocer una conclusión en presencia de un hecho o estado de cosas y ausencia de prueba contraria (la presunción de paternidad) o únicamente en ausencia de prueba contraria (la presunción de inocencia) ${ }^{43}$.

Se habla, así, de una concepción plural y, también, de una concepción funcional de las presunciones que renuncia a la idea de construir una noción auténtica o un concepto fetén y, en su lugar, postula el estudio de los diversos tipos de presunciones desde la perspectiva de su fundamento y función. Si el término «presunción», afirman, es empleado por el legislador, por los Tribunales y por los juristas de diverso modo y en una variedad de contextos o situaciones, no parece razonable restringir su utilización sólo a algunos $\operatorname{casos}^{44}$.

Las normas de presunción establecen, generalmente, una verdad procesal, es decir, obligan al juez a tener por probado algo en el proceso y se traducen en cargas de la prueba o de la argumentación para quien alega lo contrario a lo que se presume; garantizan, por eso, ciertos valores mediante la regulación de la carga de la prueba ${ }^{45}$. Estas características, como veremos, se modulan en el caso de la presunción de validez de los actos, pues ésta opera precisamente fuera del proceso, no obliga al juez a tener por probada la validez del acto y no se traduce para los destinatarios de éste en una carga de la prueba, sino más bien en la carga de la impugnación y de la argumentación de su invalidez. Sería, por consiguiente, una norma de presunción con rasgos particulares.

39 Distintas de las normas de presunción, que obligan a presumir algo, son las normas basadas o en las que subyace una presunción, que son aquellas en las que el legislador hizo una presunción pero no dictó una norma de presunción, por lo que no obligan a presumir nada. Por ejemplo, en la norma (constitucional) que establece la mayoría de edad a los 18 años subyace la presunción de que cuando una persona alcanza dicha edad adquiere un grado de desarrollo intelectual y moral que se considera suficiente para adquirir el estatus jurídico de la mayoría de edad; en la norma (reglamentaria) que prohíbe circular a más de 120 Km/h subyace la presunción de que por encima de esa velocidad se alcanza un cierto nivel de riesgo que no se debe tolerar. En tales casos hay un juicio presuntivo que constituye la ratio o fundamento de la norma, pero dicho juicio agota toda su virtualidad en la fase de creación del Derecho y no se proyecta al plano de su aplicación. Vid. J. AGUILÓ REGLA (2018: 221), que precisa que en tales casos sería mejor hablar de presuposiciones subyacente a las reglas; D. MARÍN-BARNUEVO FABO (2018: 1.276-1.280); R. GAMA LEYVA (2019: 67-76). Para numerosos autores, entre los que se encuentran los tres citados, las denominadas presunciones iuris et de iure se incluirían en estas normas en las que subyace una presunción del legislador, las cuales no serían verdaderas presunciones porque en ellas no está presente ni un razonamiento de tipo presuntivo ni la característica de la derrotabilidad que es, también, uno de los aspectos definitorios del concepto de presunción. Vid. también, L. PEÑA GONZALO y T. AUSíN DÍEZ (2001): "La inferencia de los hechos presuntos en la argumentación probatoria", en Anuario de Filosofía del Derecho, tomo XVIII, pág. 115; F. SCHAUER (2013): Pensar como un abogado. Una nueva introducción al razonamiento jurídico, Madrid, Marcial Pons, págs. 230-231; J. RAMIA (2017: 134).

40 M. GASCÓN ABELLÁN (2010: 123).

41 V. FERRERES COMELLA (2007): Justicia constitucional y democracia, 2. ${ }^{a}$ ed., Madrid, CEPC, pág. 141.

42 Por eso se habla de presunciones de derecho cuando se da por existente cierta situación jurídica (que alguien tiene deberes o derechos, que un acto es válido, etc.) y presunciones de hecho, que dan por probada cierta situación de hecho en un tiempo y un lugar. Vid. M. GASCÓN ABELLÁN (2010: 125).

43 M. GASCÓN ABELLÁN (2010: 123-126); J. AGUILÓ REGLA (2018: 217). Otros autores, como D. MENDONCA (2000: 223) hablan, de forma genérica, de afirmación base, afirmación presumida y enlace que permite el paso de la primera a la segunda; en las presunciones legales el enlace está predeterminado por el legislador y en las judiciales lo efectúa el juzgador en atención a las denominadas «máximas de experiencia».

44 Los máximos exponentes de la concepción plural de las presunciones serían M. TARUFFO e I. DENNIS. Vid. R. GAMA LEYVA (2019: 216-219). Además, como recuerda este mismo autor, son muchos los autores que, tanto en el common law como en el Derecho continental, consideran que las presunciones pertenecen al Derecho sustantivo (bienes, sucesiones, contratos, etc.) y no al procesal, pues complementan la regulación de una determinada institución y no pueden entenderse adecuadamente si no es en conexión a ellas (págs. 85-87, 167, con abundante bibliografía).

45 Vid., respectivamente, J. AGUILÓ REGLA (2018: 217, 219); M. GASCÓN ABELLÁN (2010: 125). 
Pero no es la única con rasgos específicos, pues hay normas de presunción que no tienen como ámbito operativo el proceso ${ }^{46}$. Además, la presunción de validez presenta claramente otros rasgos definitorios de las normas de presunción, como la parcialidad o preferencia anticipada a cierta solución, favoreciéndola frente a otras soluciones opuestas (pues las consecuencias de presumir la validez del acto son menos graves que las consecuencias de no presumirla); el hecho de que las presunciones no imponen ninguna creencia sobre la sustancia de fondo, sino, más bien, un «no está probado que» o un «hasta que» (el acto hay que presumirlo válido hasta que el órgano competente declare autoritativamente su invalidez); y, en fin, el que no tienen tanto que ver con la afirmación de hechos como con el proceder sobre su base, ya que su objeto es facilitar la toma de decisiones superando situaciones de incertidumbre (lo que también concurriría en este caso) ${ }^{47}$.

Por todo ello, por lo asentado que está su uso en el lenguaje jurídico, y porque otros conceptos propuestos (privilegio de creación normativa, principio de inercia, norma de validación) tienen una capacidad explicativa, analítica e incluso directiva mucho menor, voy a seguir hablando aquí de presunción de validez de los actos administrativos, aunque en el sentido indicado de norma de presunción y con el concreto fundamento, significado y efectos que paso a exponer a continuación ${ }^{48}$.

\section{FUNDAMENTO Y FUNCIÓN DE LA PRESUNCIÓN DE VALIDEZ}

Las presunciones desempeñan varias funciones en el Derecho, las cuales se relacionan con el fundamento concreto de cada una de ellas ${ }^{49}$. Las presunciones simples o judiciales se formulan con un «es presumible» y, como se anticipó, suelen expresar un juicio de regularidad o normalidad fundado en la experiencia (quod plerumque accidit), al que se reconoce una alta probabilidad de verdad y, por eso, lo más fiable es atenerse al enunciado de la presunción, de modo que, ante situaciones de incertidumbre, facilitan la prueba de los hechos ya que sólo habrá que probar el hecho base o indicio.

Sin embargo, las denominadas normas de presunción se formulan con un «se presumirá» o un «debe presumirse» y, en ellas, subyacen generalmente razones o valores de otro tipo, sobre todo garantistas, como en el caso de la presunción de inocencia o de buena fe o, como en el caso de la presunción de validez de los actos y de las normas jurídicas, razones vinculadas a la estabilización de expectativas y situaciones jurídicas que las instituciones pretenden cumplir. Por eso, no tratan de dar cuenta de una regularidad preexistente, sino de establecer hacia el futuro una regularidad o normalidad institucional (principio de seguridad jurídica, de funcionamiento del sistema y conservación del orden jurídico) ${ }^{50}$. Como se ha adelantado, no imponen creencia alguna sobre la cuestión de fondo, sino que el destinatario de la presunción es alguien obligado a actuar en algún sentido «a no ser que» o «hasta que» se pruebe o decida lo contrario.

46 Por ejemplo, el funcionario del Registro Civil está obligado a dar por acreditada la paternidad como consecuencia de la presunción de paternidad. Tomo el ejemplo de J. AGUILÓ REGLA (2018: 212, nota 14). Como dice J. DELGADO ECHEVERRÍA (2019): Validez de normas y de actos jurídicos. Estudios de Teoría General desde el derecho privado, Madrid, Marcial Pons, pág. 231, nota 27), la introducción de reglas sobre las presunciones en la LEC en relación con la prueba de los hechos en el juicio (con la correlativa derogación de las hasta entonces presentes en el CC) contribuye a olvidar el análisis de las normas de presunción que no tienen como ámbito operativo el proceso (pág. 231, nota 27). Para este autor, si se entiende la validez como corrección o adecuación a Derecho, la presunción de validez sería una norma de presunción; pero si la validez se entiende como fuerza de obligar (lo que equivale, como el mismo reconoce, al concepto de existencia) no sería una presunción sino una norma de validación (págs. 220-226).

47 D. MENDONCA (2000: 216, 226); J. AGUILÓ REGLA (2006: 24, 25) y (2018: 214); J. DELGADO ECHEVERRÍA (2019: 231, 232). Como señala J. RAMIA (2017: 130), siguiendo a BERMEJO-LUQUE, las presunciones se emplean "en condiciones de incertidumbre, cuyo contenido se mantiene en pie hasta que se aducen razones suficientes en su contra», y «articulan la exención de aportar razones para nuestras razones».

48 Habla de privilegio de creación normativa y de principio de inercia para explicar muchos de los efectos que aquí se imputan a la presunción de validez, R. LETELIER WARTENBERG (2011: 254), y de norma de validación J. DELGADO ECHEVERRÍA (2019: 233, 234). Sobre las funciones descriptivas, analíticas y directivas de los conceptos jurídicos, es fundamental el libro de S. DÍEZ SASTRE (2018): La formación de conceptos en el Derecho público. Un estudio de metodología académica: definición, funciones y criterios de formación de los conceptos jurídicos, Madrid, Marcial Pons, págs. 142-154.

49 R. GAMA LEYVA (2019: 197), quien precisa que los juristas ingleses y americanos suelen abordar de manera conjunta ambas cuestiones, como voy a hacer aquí.

50 Las normas de presunción, en efecto, suelen basarse, además de en un juicio de probabilidad o de regularidad (presunción de fallecimiento, de paternidad), en consideraciones de índole procesal (facilidad probatoria o equidad procesal: presunción de paternidad derivada de la negativa a someterse a la prueba de ADN), valorativa (presunción de inocencia), de estabilización de expectativas (presunción de constitucionalidad de las leyes y de validez de los actos). Vid., entre otros, D. MENDONCA (2000: 226); J. AGUILÓ REGLA (2006: 14, 18) y (2018: 213, 214); M. TARUFFO (2008: 151-153); M. GASCÓN ABELLÁN (2010: 125); J. DELGADO ECHEVERRÍA (2019: 232); R. GAMA LEYVA (2019: 65, 84, 198-200). 
En el caso de la presunción de validez de los actos y de las normas jurídicas en general, se trataría de un principio institucional cuyo fundamento está ligado a la idea de preservar el sistema de autoridades a las que se atribuye funciones de producción y aplicación del Derecho. Como se ha afirmado, «la eficacia del entramado institucional de autoridades depende en buena medida de dotar de una fuerza presuntiva a las decisiones que emiten tales autoridades (leyes, sentencias, resoluciones, etc.), pues la eficacia o fuerza autoritativa del Derecho se tambalearía si bastara con que cualquier agente alegara una desviación de las exigencias fijadas en las reglas que confieren tales poderes para dejar de aplicar o seguir una ley, una sentencia o un acto administrativo. De este modo, la mínima apariencia de cumplimiento de las exigencias que establecen las normas pone en marcha todos los efectos jurídicos previstos para los resultados normativos regulares y solo en virtud de un procedimiento expreso de un órgano investido de autoridad para ello será posible romper tal presunción» ${ }^{51}$.

La presunción de validez de los actos, por consiguiente, no se basa en un juicio de regularidad, normalidad o probabilidad de verdad, esto es, no se apoya en una regla de experiencia previa: que los actos administrativos que dicta la Administración suelen ser conformes a Derecho. La norma de presunción no se apoya en esto, sino que está vinculada a la propia función de estabilización y clarificación del Derecho que el acto administrativo cumple en el sistema como instrumento al servicio de la eficacia de la Administración y los intereses de los ciudadanos, a los que dota, también, de un fundamento estable en sus derechos y obligaciones ${ }^{52}$. El fundamento de la presunción reside, por ello, en razones institucionales ligadas a la seguridad jurídica y a la eficacia de la Administración y de tutela del Derecho en general, pues las consecuencias de no considerar (no presumir) los actos como válidos hasta que se anulen incidirían muy negativamente en el funcionamiento del propio sistema, ya que cualquier sujeto podría negarse a cumplir o aplicar tales actos mientras no se demostrara que se adecuan al ordenamiento ${ }^{53}$.

Si no se estableciera (expresa o implícitamente) esa norma de presunción de validez de los actos, su ejecutividad perdería seguramente su base o fundamento, como veremos al final de este trabajo. Algunas sentencias del TS han señalado, por ello, que la presunción de validez permite la ejecutividad de los actos administrativos ${ }^{54}$. Y numerosos autores destacan también esa conexión causal cuando afirman que la ejecutividad del acto es la consecuencia de su presunción de validez ${ }^{55}$.

51 Vid. A. RÓDENAS CALATAYUD (2019): "Seguridad jurídica y principios institucionales", en el Congreso Estado de Derecho y participación política. Homenaje a Jorge Malem, Tossa de Mar, 17-18 octubre 2019 (disponible en https://www.youtube.com/ watch? $v=z v i v L 9 O K 8 f A$ ), que califica a dicha presunción como un principio institucional. Los principios institucionales, señalan M. ATIENZA RODRÍGUEZ y J. RUIZ MANERO (2007: 28), expresan exigencias que derivan de lo que podemos llamar los valores internos del Derecho y del objetivo general de eficacia del Derecho y de funcionamiento eficiente de su maquinaria, mientras que los sustantivos expresan las exigencias correspondientes a los valores o a los objetivos colectivos que el sistema jurídico trata de realizar. Para G. DOMÉNECH PASCUAL (2010: 1.032-1.033), la presunción de validez no es un principio, sino una regla o conjunto de reglas, fundamentalmente porque los principios son mandatos de optimización y la presunción de validez, dice, no es algo que deba satisfacerse en la mayor medida posible. Pero, para algunos autores, el mandato de optimización no se predica de los principios en sentido estricto, sino sólo de los principios que son directrices. Vid. M. ATIENZA RODRÍGUEZ y J. RUIZ MANERO (2007: 29-34). Para J. AGUILÓ REGLA (2018: 219) presunciones como la de inocencia, buena fe, constitucionalidad de las leyes y legalidad de los actos responden a la estructura categórica típica de los principios y no a la condicional propia de las reglas (estructura a la que responderían las que los procesalistas denominan «presunciones en sentido estricto»). En mi opinión, la presunción de validez puede considerarse un principio entendido en varios de los sentidos con que los juristas utilizamos este término. Sobre ello, además de M. ATIENZA RODRÍGUEZ y J. RUIZ MANERO (2007: 25-36), G. R. CARRIÓ (1990): Notas sobre Derecho y lenguaje, Buenos Aires, Abeledo-Perrot, págs. 194-234, que considera expresamente como principio la presunción de legitimidad de los actos del poder público (pág. 206).

52 Sobre esta función del acto administrativo, H. MAURER (2011: 241); R. BOCANEGRA SIERRA (2011: 773-774); S. MUÑOZ MACHADO (2017: 166, 177); L. PAREJO ALFONSO (2015): "Algunas reflexiones sobre la vigencia de la noción de acto administrativo en el Derecho Administrativo español”, en M. REBOLLO PUIG, M. LÓPEZ BENÍTEZ y E. CARBONELL PORRAS (coords.), Régimen jurídico básico de las Administraciones Públicas. Libro homenaje al profesor Luis Cosculluela, Madrid, lustel, pág. 474.

53 M. REBOLLO PUIG (2005: 608-609, 637-638); J. DELGADO ECHEVARRÍA (2019: 229, 232). Sobre el fundamento de la presunción de validez de los actos en razones de seguridad jurídica, vid. J. L. VILLAR PALASÍ y J. L. VILLAR EZCURRA (1999: 148). Sobre la presunción de validez de la ley como forma de asegurar la certeza y funcionalidad del sistema, L. FERRAJOLI (2000): Derecho y razón. Teoría del garantismo penal, Madrid, Trotta, pág. 873.

54 STS de 3 de febrero de 1999 (rec. núm. 2803/1993). La mucho más reciente de 28 de mayo de 2020 (rec. cas. 5751/2017) señala expresamente que «la ejecutividad dimana de la presunción de legalidad».

55 J. L. VILLAR PALASÍ y J. L. VILLAR EZCURRA (1999: 148); M. SÁNCHEZ MORÓN (2020): Derecho Administrativo. Parte general, Madrid, Tecnos, pág. 551. También se percibe esa relación o vinculación en E. GARCíA DE ENTERRÍA y T. R. FERNÁNDEZ RODRÍGUEZ (2017: 560); M. BELADIEZ ROJO (1994a): Validez y eficacia de los actos administrativos, Madrid, Marcial Pons, pág. 264; Para M. REBOLLO PUIG (2019: 185) y J. ESTEVE PARDO (2016: 200) la ejecutividad es el resultado de añadir a la presunción de validez la eficacia del acto, mientras que para S. MUÑOZ MACHADO (2017: 81), «la ejecutividad solo está ligada a la presunción de validez en la medida en que sería de todo punto absurdo y antijurídico que se reconociera legalmente aquella condición a los actos 


\section{EFECTOS DE LA PRESUNCIÓN}

La presunción de validez de los actos administrativos impone el deber de aceptar el acto y actuar sin entrar a analizar si es o no conforme a Derecho hasta que un órgano competente para ello, a través del procedimiento legalmente previsto, declare autoritativamente su invalide $z^{56}$. Hasta que la anulación del acto no tenga lugar, el acto, sus efectos y la forma en que éstos se producen (ejecutividad) gozan del respaldo del Derecho por muchos vicios o irregularidades que presente y por muy graves que éstas sean. El art. 8 de la Ley General Tributaria de 1963 explicitaba claramente esta idea, al disponer que: «los actos de determinación de las bases y deudas tributarias gozan de presunción de legalidad, que sólo podrá destruirse mediante revisión, revocación o anulación practicada de oficio o a virtud de los recursos pertinentes» ${ }^{57}$.

Algún autorizado autor ha afirmado que la regla que nos ocupa significa realmente que los actos son válidos mientras no sea declarado lo contrario y que, desde el punto de vista del régimen jurídico, que es lo que importa, no hay diferencias entre ser válido y presumirse válido porque el Derecho trata a los actos como si fueran válidos ${ }^{58}$. Late aquí una identificación entre validez y existencia de los actos y entre validez y no anulación. Pero, en realidad, sí hay diferencias entre considerar que un acto sea válido y tener la obligación de actuar como si lo fuera (o sin entrar a analizar si lo es o no) hasta que sea anulado, pues si el Derecho afirmara que los actos de la Administración sujetos al Derecho Administrativo son válidos hasta que sean anulados, los pronunciamientos anulando tales actos nunca podrían tener efectos ex tunc y serían una suerte de derogación o revocación. Con esta tesis no se explicaría tampoco la razón por la que un acto válido termina convirtiéndose en inválido con su anulación y, además, se reduciría el papel de la ciencia jurídica a la contemplación acrítica del Derecho existente ${ }^{59}$.

La presunción de validez es una cualidad o un atributo que una norma predica de los actos, pero, en rigor, la presunción no deriva de ninguna cualidad intrínseca del acto, sino de una norma jurídica que utiliza como presupuesto al acto y obliga a actuar respecto a él sin entrar a analizar si es o no conforme a Derecho hasta que no sea declarado inválido de forma autoritativa ${ }^{60}$. Se trata de una norma que establece un deber no sometido a ninguna otra condición adicional o distinta de la que deriva de su propio contenido, lo que significa que si la formulamos de forma hipotética obtenemos una norma redundante: «si algo es un acto administrativo, entonces debe presumirse la validez de ese acto» (si se suprime el antecedente se mantiene la misma norma) ${ }^{61}$.

La norma que establece la presunción de validez de los actos, en efecto, obliga a aceptar una calificación jurídica (que puede ser errónea) salvo declaración expresa en contra por parte de los órganos competentes ${ }^{62}$. Así, el propio ordenamiento jurídico dispone que, a partir del momento en que se dicta un acto admi-

que no se presuman válidos. Pero la ejecutividad no es un efecto necesario de la presunción de validez. Sí lo es el reconocimiento de que producen efectos todos los actos que se presumen válidos».

56 Autoritativamente no por la corrección o solidez del pronunciamiento, sino por el estatus del órgano que lo dicta y, por tanto, con independencia de su contenido. Sobre ello, con carácter general, H. L. A. HART (1982), "Mandatos y razones jurídicas dotadas de autoridad", en Isonomía, núm. 6, págs. 94-99; F. SCHAUER (2013: 78).

57 La recoge ahora el art. 8 de la Ley Foral 13/2000, de 14 de diciembre, General Tributaria.

58 A. NIETO GARCíA (1994: 16, 17). Eso era lo que disponía el art. 45 de la Ley de Procedimiento Administrativo de 1958 («Los actos de la Administración serán válidos y producirán efecto desde la fecha en que se dicten, salvo que en ellos se disponga otra cosa»), pero la doctrina entendía que ello debía entenderse en el sentido de una presunción de validez y no como una afirmación absoluta. Vid. E. GARCÍA DE ENTERRÍA y T. R. FERNÁNDEZ RODRÍGUEZ (1974): Curso de Derecho Administrativo, tomo I, Madrid, Civitas-Revista de Occidente, pág. 339. tencia.

59 Vid. L. FERRAJOLI (2011: 498), donde critica las tesis de Kelsen y Hart que identifican la validez de las normas con su exis-

60 M. REBOLLO PUIG (2005: 591) señala que la presunción de validez es una cualidad de los actos, pero de inmediato precisa que el deber de actuar como si el acto fuera válido no nace de cada acto sino del ordenamiento jurídico, pues el acto no es más que el supuesto de hecho para que opere esa norma imperativa. M. GASCÓN ABELLÁN (2010: 124) también destaca que este tipo de presunciones no son un resultado asertivo, sino normas de comportamiento que obligan a reconocer una conclusión en presencia de un hecho o estado de cosas en ausencia de prueba (aquí declaración de invalidez) contraria. En el mismo sentido, D. MENDONCA (2000: 220); J. AGUILÓ REGLA (2018: 214, 219); J. DELGADO ECHEVERRÍA (2019: 231).

61 J. AGUILÓ REGLA (2006: 24) y (2018: 218).

62 Sobre la «aceptación» como concepto que mejor expresa la idea de presunción, D. MENDONCA (2000: 217-218), quien precisa que la aceptación está directamente vinculada con la acción, en el sentido de que genera la expectativa de que se realicen determinados actos conforme con los contenidos aceptados (en nuestro caso, ese deber de comportarse y actuar respecto del acto sin entrar a analizar si es o no conforme a Derecho hasta que el órgano competente para ello no declara su invalidez), lo cual es compatible con no tener creencia alguna respecto de tal aceptación o, incluso, con creer que es falsa (en el caso, que el acto no es conforme a Derecho y, por eso, impugnarlo en vía administrativa o judicial). 
nistrativo, debe presumirse que es conforme a Derecho hasta que se declare formalmente que no concurre tal conformidad o adecuación a las normas que regulan su producción. La resolución administrativa o judicial que declara que el acto no se adecua al ordenamiento jurídico no es, en realidad, la prueba de ningún hecho, ni siquiera es una prueba, sino un juicio de adecuación del acto a sus requisitos de validez ${ }^{63}$. Además, ese juicio de adecuación sólo es relevante jurídicamente en determinados procedimientos orientados, precisamente, a declarar de forma principal (o incidental) la invalidez del acto. La presunción de validez queda destruida, no por la prueba de la no validez, sino por un pronunciamiento de invalidez revestido de autoridad ${ }^{64}$.

La presunción, como puede verse, no va dirigida al juez, como ocurre con otros tipos de presunciones, ni está llamada a operar en el seno de un proceso, como acaece normalmente, sino que se dirige a todos los demás sujetos que operan en el tráfico jurídico, incluidas las propias Administraciones públicas (art. 39.4 y 5 LPAC). Tales sujetos, mientras no se declare su invalidez, tendrán que aceptar y tratar al acto como válido y, por tanto, en función de las circunstancias de cada caso, tendrán que cumplir o respetar su contenido, podrán exigir su complimiento y deberán adoptar sus decisiones como si el acto fuera conforme a Derecho. Si bien, como es lógico, podrán poner en marcha los mecanismos normativamente previstos para que se declare su invalidez si lo reputan contrario a Derecho. De este modo, la presunción no opera, o lo hace de otro modo, respecto de los órganos competentes para formular juicios de validez revestidos de autoridad, que, en nuestro caso, no sería sólo la Jurisdicción, sino, también, la propia Administración autora del acto a través de los recursos administrativos y de la revisión de oficio. Algunas sentencias hablan, por ello, de una eficacia extraprocesal (y extraprocedimental habría que añadir) de la presunción ${ }^{65}$.

La presunción surge, y el mandato de la norma que la establece opera, desde que se dicta el acto, aunque no sea eficaz porque no se haya notificado o su eficacia quede demorada como consecuencia de una condición suspensiva o, incluso, ya no sea eficaz porque estaba sujeto a un término que ya se haya producido. En este sentido, se ha afirmado que la presunción de validez expresa (o más bien fundamenta) la fuerza jurídica del acto, no su eficacia ni, desde luego, su firmeza que, si acaso, impedirá o dificultará la destrucción de la presunción ${ }^{66}$.

La consecuencia o el efecto de la presunción es, como ya se ha señalado, el deber de aceptar y proceder como si los actos administrativos fueran plenamente conformes a Derecho hasta que su invalidez sea declarada, bien de modo principal en un procedimiento impugnatorio destinado a declarar la invalidez del acto, anulándolo con carácter general y definitivo, o bien incidentalmente en el marco de otro procedimiento distinto y a los solos efectos de reconocer su invalidez como presupuesto o fundamento de otras consecuencias o efectos jurídicos distintos a su anulación. Por eso, la presunción no opera ni en los procedimientos o procesos en los que su objeto principal es declarar la no conformidad a Derecho del acto y, en su caso, anularlo [art. 71.1.a) LJCA], ni tampoco, como veremos más adelante, en aquellos otros de carácter incidental en los que un órgano (administrativo o judicial) puede apreciar la invalidez del acto como presupuesto de hecho de una norma que ha de aplicar, pero cuyas consecuencias son distintas a la anulación del acto (inaplicación del acto, imposición de una sanción, reconocimiento de la responsabilidad de la Administración, anulación de otro acto distinto, etc.).

La presunción de validez impone la carga de la impugnación del acto al sujeto (legitimado) que pretenda evitar que la presunción convierta en inmune al acto por el transcurso de los plazos impugnatorios y que sus efectos se mantengan o, en su caso, se sigan produciéndose ${ }^{67}$. La presunción de validez también afecta a la propia Administración que ha dictado el acto, pues, si pretende desconocerlo, tendrá que, según los casos, revisarlo de oficio, revocarlo o poner en marcha el proceso de lesividad. Si el acto no gozara de dicha presunción y, por tanto, no existiera ese deber de aceptar y comportarse como si fuera conforme a Derecho, sus destinatarios, cualquier otro afectado o la propia Administración podrían permanecer pasivos o desconocerlo sin más.

63 M. REBOLLO PUIG (2005: 618, nota 48); J. DELGADO ECHEVARRÍA (2019: 232-233).

64 Vid. J. DELGADO ECHEVERRÍA (2019: 232-233).

65 STS de 3 de febrero de 1999 (rec. núm. 2803/1993).

66 M. REBOLLO PUIG (2005: 593-594). Como también señala L. PAREJO ALFONSO (2016: 530) la presunción se refiere precisamente a la validez, lo que explica que opere desde que se dicte el acto, pero nada dice sobre su eficacia, que puede quedar supeditada a la aprobación o notificación del acto (pág. 530). Destaca también la necesidad de distinguir la presunción de validez de la eficacia del acto, S. MUÑOZ MACHADO (2017: 75-84).

67 STS de 12 de febrero de 2009 (rec. núm. 9511/2004); SAN 16 de octubre de 2019 (rec. núm. 180/2017). En la doctrina, entre otros, L. COSCULLUELA MONTANER (2019: 362); L. PAREJO ALFONSO (2016: 530), entre otros. Otros autores, sin embargo, consideran que la carga de la acción deriva de la ejecutividad. Vid. D. MARÍN-BARNUEVO FABO (2018: 1.295-1.296). 
Pero la presunción de validez no se reduce, ni mucho menos, a la carga de impugnar el acto, que sólo incumbe a los sujetos que pretenden que ésta se declare, o, en el caso de la Administración, a proceder a su revisión, revocación o declaración de lesividad y posterior impugnación. Como la presunción afecta a todos, protege a los ciudadanos de la libre apreciación que otros sujetos, incluida también la Administración, pudieran realizar sobre la validez de los actos administrativos ${ }^{68}$. Así, la Administración no puede negarse, sin más, a abonar una subvención que ha concedido porque considera que incurre en un vicio de nulidad, del mismo modo que un Ayuntamiento no puede denegar una licencia de autotaxi esgrimiendo que el permiso de conducir del solicitante carece de validez, pues, si es competente para ello, tendrá antes que anular el acto y, si no lo es, deberá instar a quien proceda su anulación. Por eso, constituye un error considerar que la presunción de validez es en todo caso un privilegio de la Administración o que existe una presunción similar en los actos y negocios de los particulares ${ }^{69}$.

La presunción de validez no altera el principio de que «quien alega prueba» ni impone, desde luego, el deber de que en el procedimiento o proceso debe partirse de la base o suposición de que el acto se ajusta al ordenamiento jurídico ${ }^{70}$.

La presunción de validez, en efecto, no afecta a las reglas sobre la carga de la prueba, que siguen siendo las mismas en el procedimiento administrativo de recurso y en el proceso contencioso-administrativo, incluido el principio de facilidad probatoria ${ }^{71}$. Ahora bien, sobre el sujeto que impugna el acto o ejerce la acción de nulidad (art. 106.1 LPAC), y sobre la Administración que lo revisa o revoca o lo impugna en el proceso de lesividad (arts. 106.1, 109.1 y 107 LPAC), pesa también, en virtud del principio de que «quien alega debe probar lo que sostiene», la carga de justificar o explicitar (convincentemente) los motivos que fundamentan su pretensión de anulación o, en el caso de la Administración, de motivar su declaración de que el acto no es conforme a Derecho.

Centrándonos en el procedimiento de recurso y en el proceso contencioso, la carga de impugnar, derivada de la presunción de validez, implica también la de justificar las razones (fácticas y jurídicas) por las cuales se considera que el acto es contrario al ordenamiento, pues, como es obvio, no cabe la impugnación del acto sin más y esperar a que sea la Administración la que demuestre la presencia de todos y cada uno de los requisitos de validez del acto, o a que, cuando se interponga un recurso, lo haga de oficio el órgano

68 M. REBOLLO PUIG (2005: 604-606, 637).

69 M. REBOLLO PUIG (2005: 606, 634-637) y (2019): "Relaciones entre la Administración y los Tribunales. La autotutela adminis-

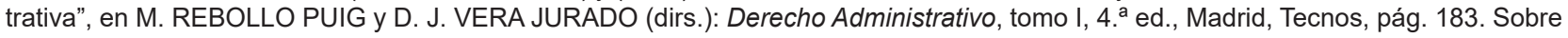
la inexistencia de una presunción similar en los actos de los particulares, vid. también, con especial claridad, J. ESTEVE PARDO (2016: 202, 216). H. KELSEN (2011): "La garantía jurisdiccional de la Constitución (la justicia constitucional)", en Anuario Iberoamericano de Justicia Constitucional, núm. 15, señalaba, por ello, que «habitualmente los actos de los particulares y los actos de las autoridades son tratados de manera diferente. En general se constata una cierta tendencia a tratar los actos de las autoridades públicas, aun los irregulares, como válidos y obligatorios hasta que otro acto de autoridad los haga desaparecer» (pág. 267). Considera, por el contrario, que los actos de los particulares también gozan de una presunción similar, R. PARADA VÁZQUEZ (2017: 67). Pero, contra lo que sostiene PARADA, la negación de una presunción similar en el Derecho privado no supone, en modo alguno, la necesidad de homologar o validar todos los actos jurídicos privados, pues es claro que quien sostenga, por ejemplo, que un testamento no se ha otorgado válidamente o un contrato es nulo tiene la carga de acudir al órgano judicial y demostrar que no concurren sus condiciones de validez. Pero, eso no quiere decir que exista una presunción de validez o que las cosas funcionen igual que en el Derecho administrativo, pues el particular que considere, por ejemplo, que el contrato es inválido puede perfectamente negarse a abonar el precio de la cosa ya entregada o del servicio ya prestado sin necesidad de que se declare antes su nulidad y, entonces, será la otra parte, que sostiene la validez del contrato, la que tendrá que acudir al órgano judicial.

70 En esto difiere la denominada presunción de constitucionalidad de las leyes, pues la cualidad democrática de la ley en cuanto que es expresión de la voluntad popular, así como la circunstancia de que es más grave anular una ley que un acto de la Administración dado el vacío y la inseguridad que se crea, lleva a sostener que sólo procede declarar su inconstitucionalidad cuando se haya producido una "clara e inequívoca colisión» con la CE o, según otros, a que en caso de duda ha de resolverse a favor de la constitucionalidad de la ley (in dubio pro legislatore). Vid. E. GARCÍA DE ENTERRÍA (2006): La Constitución como norma y el Tribunal Constitucional, $4 .^{\text {a }}$ ed., Madrid, Civitas, págs. 101-103; I. DE OTTO PARDO (1987): Derecho Constitucional. Sistema de fuentes, Barcelona, Ariel, pág. 148; V. FERRERES COMELLA (2007: 131 y ss.). Como señala el primero de ellos, la presunción de constitucionalidad de las leyes no es la simple afirmación de que cualquier ley se tendrá por válida hasta que sea declarada inconstitucional, sino que implica algo más: una confianza otorgada al legislativo en la observancia e interpretación correcta de la CE, que cuando la ley está redactada en términos tan amplios que puede permitir varias interpretaciones hay que optar por la que se mantenga dentro de los límites constitucionales y que una ley sólo puede ser declarada inconstitucional mas que cuando no exista duda razonable sobre su contradicción con la CE (pág. 102). Aunque esto último es negado por algunos autores que consideran que la presunción de constitucionalidad no es tan fuerte sino mas moderada, de modo que no es necesario que los argumentos en contra de la ley sean de tanto peso como para disipar cualquier duda entre personas razonables. Vid. V. FERRERES COMELLA (2007: 193-197).

71 M. REBOLLO PUIG (2005: 62); G. DOMÉNECH PASCUAL (2010: 1035); J. A. XIOL RIOS (2013): "Artículo 57. Efectos", en M. SÁNCHEZ MORÓN y N. MAURANDI GUILLÉN, Comentarios a la Ley 30/1992, Valladolid, Lex Nova, pág. 407; S. MUÑOZ MACHADO (2017: 83); D. MARÍN-BARNUEVO FABO (2018: 1.294). 
administrativo o judicial. Es el recurrente el que tiene que argumentar en su recurso administrativo o en la demanda [arts. 115.1.b) LPAC y 45.5 y 56.1 LJCA) que el acto es contrario a Derecho, aunque ello se vea, en cierto modo, modulado o atenuado por la facultad que tiene el órgano administrativo o jurisdiccional que conoce el asunto para apreciar de oficio motivos no alegados por las partes (arts. 119.3 LPAC y 33 LJCA) ${ }^{72}$. La Administración, por su parte, tendrá que contraargumentar justificando la concurrencia de los requisitos de validez que el recurrente haya cuestionado y deberá probar aquellos hechos en que se sustente el acto y hayan sido negados por el particular, pues a ella corresponde su prueba según las reglas generales.

EI TS ha destacado, en este sentido, que la presunción de validez de los actos administrativos «impone la carga de recurrir en sede judicial la resolución administrativa, pudiendo obviamente basarse la impugnación en la falta de prueba de los hechos que sirven de presupuesto fáctico al expresado acto», de modo que dicha presunción «no altera las reglas de distribución de la carga de la prueba que fija el art. 217 de la LEC, ni supone otorgar presunción de certeza a los hechos que en las resoluciones de la Administración se declaren probados» ${ }^{73}$.

La presunción de validez no incide tampoco en la suspensión de la eficacia de los actos, por lo que carece de relevancia a la hora de decidir si se adopta o no la medida cautelar de suspensión, la cual procederá, o no, teniendo en cuenta únicamente si concurren los requisitos propios y específicos de tales medidas ${ }^{74}$. La presunción no puede esgrimirse, por ello, para sostener la apariencia de buen derecho, sino que esta apariencia debe apreciarse objetivamente en atención a las características de regularidad o adecuación a Derecho que objetivamente presente el acto en cuestión ${ }^{75}$.

La presunción, en fin, no permite ni, desde luego, impone a la Administración o a los jueces la obligación de que consideren el acto ajustado a Derecho en caso de duda sobre su validez (por ejemplo, porque su invalidez no es manifiesta debido a que hay dudas de Derecho o porque la prueba no es concluyente), pues no concurre ninguna razón que justifique el que la propia presunción haya de formar parte del razonamiento del juez o de la Administración cuando se pronuncian sobre la adecuación a Derecho del acto ${ }^{76}$. En la medida en que, como se ha visto, la norma que establece la presunción de validez no se fundamenta en un juicio de regularidad, normalidad o probabilidad de verdad, esto es, no se apoya en un «es presumible» que el acto sea válido porque la Administración suele respetar todos sus requisitos de validez, no puede esgrimirse que resultaría más seguro atenerse a lo que esa presunción determina como verdadero, ya que nada determina en tal sentido.

\section{0. ÁMBITO OBJETIVO DE LA PRESUNCIÓN: SU APLICACIÓN A TODOS LOS ACTOS ADMINISTRATIVOS}

La validez no sólo se presume de los actos aparentemente válidos, sino de todos los actos administrativos que puedan considerarse tales, al margen, pues, de la apariencia de validez o regularidad que presenten.

En efecto, como ya he indicado, debido a razones institucionales ligadas a la estabilización de expectativas y a la eficacia del Derecho, éste presume la validez de los actos administrativos que presentan una mínima apariencia de adecuación a las normas sobre la producción jurídica. Si el acto administrativo tiene una mínima apariencia de tal, esto es, aparece prima facie como una instancia de aquello que pretende ser, porque cumple unos mínimos requisitos de existencia o validez constitutiva, el acto se presume válido. Por eso, la sujeción al Derecho Administrativo de que habla el art. 39.1 LPAC se refiere a que sea un acto administrativo y no un acto privado de la Administración, pero no exige que el acto administrativo presente una

72 G. DOMÉNECH PASCUAL (2010: 1.035); L. COSCULLUELA MONTANER (2019: 362).

73 STS de 12 de febrero de 2009 (rec. núm. 9511/2004) (FJ 5), la cual precisa que el expediente administrativo puede contener ya el respaldo probatorio de la resolución cuya legalidad se cuestiona, por lo que «la mera negación de los hechos en el escrito de demanda no traslada a la Administración la carga de acreditar nuevamente los hechos» (FJ 6). La SAN de 16 octubre de 2019 (rec. núm. 180/2017), también citada, habla de la carga de la impugnación del acto y «la de acreditar, en su caso, la contravención con el ordenamiento jurídico» (FJ 5).

74 Así, G. DOMÉNECH PASCUAL (2010: 1.046); J. A. XIOL RÍOS (2013: 407).

75 M. REBOLLO PUIG (2005: 622).

76 M. REBOLLO PUIG (2005: 520); J. A. XIOL RIOS (2013: 407). Sin embargo, la presunción de constitucionalidad de la ley sí obliga al Juez constitucional a que, en caso de duda, se incline por la conformidad de la ley a la Constitución. Sobre las razones que justifican esta deferencia hacia el legislador (algunas ya apuntadas en la nota 67), vid. E. GARCÍA DE ENTERRÍA (2006: 102-103) y, sobre todo, V. FERRERES COMELLA (2007: 151-196). 
apariencia de conformidad o adecuación a Derecho ${ }^{77}$. Por el contrario, si no estamos en presencia de algo que pueda ser considerado un acto administrativo, no hay acto del que poder presumir su valide ${ }^{78}$.

Como la presunción consiste en comportarse frente a un acto administrativo sin entrar a analizar si es o no conforme a Derecho, se aplica tanto a los actos anulables como a los actos nulos de pleno derecho ${ }^{79}$. Las diferencias entre estos dos tipos o grados de invalidez no residen en que los primeros se presuman válidos y los nulos de pleno derecho no. El art. 39.2 LPAC no hace ninguna distinción al respecto y eso es, precisamente, lo que se deduce de todo el sistema (de la regulación de la revisión de oficio, de la posibilidad de suspender la eficacia de los actos nulos cuando son objeto de revisión o se han recurrido vía administrativa o contenciosa, etc. $)^{80}$. Como se ha afirmado, considerar que la presunción no opera para los actos nulos de pleno derecho supone negarle a la presunción de validez su significado más propio y toda su utilidad y dejar abierta de par en par la puerta de la inseguridad y el desorden, que es precisamente lo que pretende evitarse con la presunción ${ }^{81}$.

La presunción de validez también se predica del silencio positivo, ya que se trata, a todos los efectos, de un acto administrativo finalizador del procedimiento, pero no del silencio negativo, que no es un acto administrativo, sino una mera ficción en interés del particular (art. 24.2 LPAC).

Cuando no se trate de resultados institucionales (actos, contratos, reglamentos), sino de actuaciones materiales o de la inactividad material de la Administración, no cabe hablar de validez sino de legalidad, pues, como ya he dicho, predicados como válido, inválido, nulo, anulable, tienen sentido para calificar resultados institucionales, pero no respecto de acciones que no lo sean. Sería absurdo, por ejemplo, calificar el acto de una persona consistente en dar muerte a otra como nulo de pleno derecho, a pesar de que vulnere una norma imperativa ${ }^{82}$. Por eso, el art. 32.2 LJCA dispone que si el recurso contencioso-administrativo tiene por objeto una actuación material constitutiva de vía de hecho, «el demandante podrá pretender que se declare contraria a Derecho», y el art. 71.1.a) establece que la sentencia estimatoria declarará «no ser conforme a Derecho y, en su caso, anulará total o parcialmente la disposición o acto recurrido o dispondrá que cese o se modifique la actuación impugnada». En estos casos, como en el supuesto de las irregularidades no invalidantes, puede hablarse de ilegalidad sin invalidez.

Ahora bien, ¿cabe hablar de una presunción de legalidad de los actos administrativos distinta de su presunción de validez?

\section{PRESUNCIÓN DE VALIDEZ Y ¿PRESUNCIÓN DE LEGALIDAD?}

M. Rebollo, en un profundo y sugerente estudio sobre el tema, ha señalado que la presunción de validez sólo puede destruirse en el seno de un procedimiento (administrativo o judicial) dirigido a anular o a declarar la nulidad del acto y privarlo así de su fuerza jurídica ${ }^{83}$. Si el acto no es anulado en vía administrativa o judicial -continua- la presunción de validez no se destruye, aunque puede destruirse su presunción de

77 Como parecen entender G. DOMÉNECH PASCUAL (2002: 228) y R. LETELIER WARTENBERG (2011: 245).

78 M. REBOLLO PUIG (2005: 614-615); L. PAREJO ALFONSO (2016: 530).

79 A. GALLEGO ANABITARTE y A. MENÉNDEZ REXACH (2001: 211, 232); T. CANO CAMPOS (2004): La invalidez sobrevenida de los actos administrativos, Cizur Menor, Thomson Civitas, pág. 186. M. REBOLLO PUIG (2005: 608) y (2018: 107); D. BLANQUER CRIADO (2014: 1286, 1294); L. PAREJO ALFONSO (2016: 530), de forma implícita al afirmar que basta con una mínima apariencia de acto; S. MUÑOZ MACHADO (2017: 84 y 178); J. A. SANTAMARÍA PASTOR (2018), Principios de Derecho Administrativo, II, 5. ${ }^{a}$ ed., Madrid, lustel, pág. 131; G. FERNÁNDEZ FARRERES (2018: 773 y 806); L. COSCULLUELA MONTANER (2019: 362); P. MENÉNDEZ GARCÍA (2019): "La invalidez de los actos administrativos", en P. MENÉNDEZ y A. EZQUERRA (dir.), Lecciones de Derecho Administrativo, Cizur Menor, Civitas Thomson Reuters, págs. 339-340; M. SÁNCHEZ MORÓN, (2020: 567). En contra, J. GARCÍA LUENGO (2002: 53-54); R. BOCANEGRA SIERRA (2012: 128); J. ESTEVE PARDO (2016: 203).

80 Me he ocupado de las diferencias entre nulidad y anulabilidad, en T. CANO CAMPOS (2017) y (2018: 7-26), con abundante bibliografía.

81 M. REBOLLO PUIG (2005: 608-609). En opinión de S. MUÑOZ MACHADO (2017: 178) «el interés general a que responde toda la actividad de la Administración (art. 103 CE) no permite que cualquier administrado pueda oponerse al cumplimento de los actos administrativos, desobedeciendo o desconsiderando la declaración que contenga, justificando su actitud en que, según su valoración jurídica, los actos incurren en nulidad absoluta».

82 M. ATIENZA RODRÍGUEZ y J. RUIZ MANERO (2003: 719) de quienes tomo el ejemplo.

83 M. REBOLLO PUIG (2005: 591-592) define así la presunción de validez: «es la cualidad de los actos administrativos en cuya virtud existe el deber de actuar y decidir partiendo de la premisa de que los actos administrativos son válidos en tanto no se declare su nulidad o sean anulados»; «la presunción que estudiamos significa que no cabe negar esa fuerza jurídica ni prescindir de ella mientras el acto no sea declarado nulo o sea anulado». 
legalidad, que sería algo distinto. Ello tiene lugar, dice, no sólo en el supuesto de las irregularidades no invalidantes, sino también en otros muchos supuestos como, por ejemplo, cuando se sanciona a un funcionario por la adopción de «acuerdos manifiestamente ilegales», cuando el hecho de dictar «un acto administrativo ilegal» es constitutivo de delito y el juez impone la pena, cuando en los conflictos de competencia se declara la incompetencia de una Administración al dictar un acto y, por tanto, «la ilegalidad» de éste, o, en fin, cuando se aprecia la responsabilidad patrimonial de la Administración por un «acto administrativo ilegal». En todos estos supuestos, concluye, se parte de la ilegalidad del acto y, en consecuencia se destruye su presunción de legalidad, pero el acto no se anula ni se ha anulado previamente (incluso puede que ya no se pueda anular) y, por tanto, no se destruye su presunción de validez, pues ello sólo tiene lugar cuando se hace un pronunciamiento expreso de invalidez y se niegan todos o parte de los efectos jurídicos del acto ${ }^{84}$.

Pero, todo esto, creo que puede explicarse de otro modo sin necesidad de escindir la invalidez de la ilegalidad y, por tanto, sin tener que distinguir entre una presunción de validez y otra de legalidad que no se encuentra consagrada en ningún sitio y que se aleja, además, de su uso común entre los juristas -y el propio ordenamiento- donde ambas expresiones se utilizan de forma indistinta.

En los casos referidos, en efecto, puede entenderse, tal y como he tratado de reflejar más arriba en la definición ofrecida, que la presunción de validez (y no sólo una supuesta presunción de legalidad) también ha sido destruida, pues ese «debe presumirse» en que consiste la presunción no ha vinculado al órgano en cuestión. Lo que ocurre es que la presunción de validez no se ha destruido en un proceso principal cuya finalidad es anular el acto y privarle, en la medida en que otros principios del sistema no lo impidan, de sus efectos pasados y futuros, sino en un procedimiento incidental en el que se aprecia la invalidez ( $y$, por tanto, se destruye la presunción) como presupuesto de una decisión cuyos efectos o consecuencias son distintas a la anulación: inaplicar un acto o una norma, castigar a un funcionario, determinar la Administración competente, declarar la responsabilidad patrimonial, etc. ${ }^{.5}$.

En tales casos, el Derecho sólo exige un pronunciamiento de invalidez desde el punto de vista del antecedente o condiciones (de los vicios de validez), no desde el consecuente o los efectos propios de la invalidez, porque las consecuencias que prevé la norma son distintas a la anulación o declaración erga omnes de invalide $z^{86}$. El vicio que concurre determina la invalidez del acto, pues no se trata de una simple irregularidad no invalidante respecto de la que se pueda afirmar que no hay invalidez, pero sí ilegalidad o antijuridicidad. Por eso, en estos supuestos en los que la norma que ha de aplicarse sólo contempla el reconocimiento o declaración de invalidez como presupuesto de hecho de una consecuencia jurídica distinta a la anulación del acto (para lo que probablemente el órgano en cuestión no tiene competencia o el procedimiento seguido no es el procedente), no creo que sea necesario escindir ilegalidad e invalidez y concluir que, en tales casos, se destruye la presunción de legalidad, pero no la de validez.

Esto está relacionado con los elementos de la teoría de la invalidez: los vicios que concurren, el procedimiento y el órgano competente para declararlos, las consecuencias de la invalidez y los efectos de los pronunciamientos que la declaran ${ }^{87}$. Tales elementos pueden ser combinados de modos diferentes en función de los fines a alcanzar o de los intereses que se pretendan tutelar. Del mismo modo que cualquier

84 M. REBOLLO PUIG (2005: 596-601). En el mismo sentido S. MUÑOZ MACHADO (2017: 82). Considera, sin embargo, forzada la distinción entre legalidad y validez en estos casos, R. LETELIER WAETENBERB (2011: 69, nota 64). Para D. MARÍN-BARNUEVO FABO (2018: 1.293) «el significado de la presunción de validez y el de la presunción de legalidad es coincidente».

85 El propio M. REBOLLO PUIG (2005) reconoce algunos supuestos en los que se está actuando contra la presunción de validez de los actos sin que antes se hayan anulado. Además de en los recursos indirectos contra reglamentos (pág. 623), lo reconoce en los que denomina recursos indirectos contra actos, esto es, en los recursos en los que se impugna un acto fundándose en la invalidez de otro no anulado que constituye su presupuesto por cuanto que se ha dictado en aplicación de éste. Por ejemplo, se impugna el nombramiento de un funcionario con fundamento en la invalidez de las bases de la convocatoria, o la multa coercitiva en la invalidez del acto cuya ejecución se pretende, o el reintegro de una subvención en la invalidez de las condiciones impuestas en el acto de otorgamiento, etc. En tales casos, él mismo reconoce, atinadamente, que la presunción de validez del acto base (o acto en virtud del cual se ha dictado el acto que se impugna) no opera y aunque dicho acto no se puede anular sí que se puede apreciar su invalidez a los solos efectos de declarar la nulidad del acto de aplicación (págs. 624-625).

86 En este sentido conviene precisar que, a propósito de la invalidez, podemos referirnos tanto a sus condiciones o antecedentes (los vicios de invalidez) como a sus consecuencias (a cuáles son los efectos de que un acto administrativo inválido). Así, en ocasiones decimos que un acto es inválido, para significar que de ello se derivan determinados efectos o consecuencias jurídicas (por ejemplo, que el acto debe ser ineficaz), mientras que otras veces la invalidez apunta a las condiciones o antecedentes de lo que calificamos como tal, y entonces decimos, por ejemplo, que un acto es inválido porque ha sido dictado cumpliendo los requisitos de producción y contenido previstos en el art. 34 de la LPAC. Sobre ello, J. A. SANTAMARÍA PASTOR (1975: 49, 61-69); J. VILLAR PALASÍ y J. L. VILLAR EZCURRA (1999: 154-155); M. ATIENZA RODRÍGUEZ y J. RUIZ MANERO (2003: 720); T. CANO CAMPOS (2017: 4).

87 T. CANO CAMPOS (2017: 4-5). 
Juez o Tribunal puede dejar de aplicar los reglamentos ilegales, pero no los pueden anular o, en el modelo de control difuso de constitucionalidad de las leyes (y en el nuestro si la ley es preconstitucional), los jueces ordinarios pueden inaplicar las leyes inconstitucionales, pero no declarar su inconstitucionalidad y nulidad, aquí, mutatis mutandis, ocurre algo similar. El Derecho reserva la anulación de los actos administrativos inválidos a la competencia ciertos órganos (administrativos y judiciales) a través de determinados procedimientos, pero no impide que fuera de esos cauces otros órganos distintos, sin necesidad de plantear una cuestión prejudicial, puedan apreciar su invalidez a otros efectos distintos a los de su anulación, destruyendo así, en el caso concreto y a esos solos efectos, la presunción de validez de que gozan ${ }^{88}$.

\section{CONCLUSIONES}

Es hora de sacar conclusiones. La presunción de validez de los actos administrativos aparece consagrada expresamente desde hace tiempo en nuestros textos positivos y es utilizada por los juristas en sus razonamientos prácticos y teóricos. Es un concepto que tiene un fundamento sólido en nuestro Derecho y una clara funcionalidad. Por eso, conviene analizarlo cuidadosamente y no desecharlo sin más, ya que lo oportuno en el Derecho es realizar un análisis funcional de los conceptos y ver si realmente tienen utilidad ${ }^{89}$.

La presunción de validez de los actos se justifica en razones institucionales ligadas a la seguridad jurídica y a la eficacia del Derecho, que se verían fuertemente resentidas si cualquiera pudiera, en cualquier momento, desligarse de lo que determinan las Administraciones Públicas cuando dictan sus actos administrativos. Sin embargo, como se ha visto, hay autores que consideran que podría prescindirse perfectamente de ella, pues la carga de impugnar los actos administrativos, que, según ellos, sería el efecto principal de la presunción de validez, traería causa, más bien, de la ejecutividad, esto es, de la necesidad de oponerse a la fuerza de obligar del acto. Pero la pregunta que surge, entonces, es si dicha fuerza de obligar del acto, esa ejecutividad, tendría sentido si el ordenamiento no impusiera, previamente, de forma expresa o implícita, su presunción de validez.

A este respecto, conviene precisar que el ordenamiento jurídico otorga tutela o protección a los actos que respetan las normas que determinan su contenido y establecen su forma de producción, ya que lo que hace el acto es declarar lo que es el Derecho en el caso concreto. Por eso, debe ser lo que el contenido de un acto dice que debe ser cuando el acto sea válido o conforme al Derecho que aplica y debe respetar. Si el Derecho establece determinados requisitos de validez y un acto administrativo no los cumple, el acto no debe producir efectos ni gozar de ejecutividad, pues toda la actuación administrativa debe realizarse «con sometimiento pleno a la Ley y al Derecho», según dispone el art. 103.1 de la CE. Pero, como se ha visto, por razones institucionales ligadas a la efectividad del Derecho y al interés general al que responde la actuación de la Administración, así como a la propia función de estabilización y clarificación del Derecho que cumplen los actos administrativos (en beneficio de todos los sujetos, también del particular), el ordenamiento obliga a presumir su validez, de modo que el acto produce efectos de forma imperativa e inmediata y surge el deber de actuar sin entrar a analizar si es o no conforme a Derecho hasta que se declare autoritativamente su invalidez. Hasta que esto no tenga lugar, el acto y sus efectos gozan del respaldo del Derecho por muchos vicios o irregularidades que presente y por muy graves que estas sean. Hay así una escisión entre validez y eficacia (y ejecutividad) que da lugar a que puedan producirse efectos jurídicos no conformes a Derecho. Por eso, aunque la fuerza de obligar del acto sólo debiera derivar de su validez o conformidad a Derecho, realmente deriva, por las razones apuntadas, de su presunción de validez desde el momento en que existe o se dicta, que trata así de legitimar o reforzar en todos los supuestos (esto es, con independencia de que el acto sea o no conforme a Derecho) su eficacia y ejecutividad.

La presunción de validez constituye, por consiguiente, una institución que cumple o satisface una importante función de clarificación y estabilización de expectativas y de situaciones jurídicas, función a la que sirve el propio acto administrativo, pero que no cumpliría realmente si cualquiera lo pudiera ignorar tras realizar su particular juicio de legalidad, por lo que la presunción refuerza esa función y, con ello, contribuye a la seguridad jurídica y a que el funcionamiento del sistema sea eficaz. La presunción establece, asimismo, una

88 También alude a que en ocasiones la declaración de invalidez no arrastra la nulidad, A. NIETO GARCíA (1994: 22, 24), lo que, en su opinión, que comparto plenamente, «resulta explicable desde un punto de vista competencial».

89 M. ATIENZA RODRíGUEZ: "Prólogo" al libro J. DELGADO ECHEVERRÍA (2019), pág. 21. Vid. también S. DíEZ SASTRE (2018: 142-154). 
conexión causal entre la validez, la eficacia y la ejecutividad de los actos administrativos, los cuales deben ser obedecidos por todos y no pueden ser desconocidos, sin más, por la Administración, aún en caso de ilegalidad, por lo que explica convincentemente el estatus de los actos administrativos contrarios a Derecho que no han sido declarados inválidos por los órganos competentes para ello.

La presunción de validez de los actos administrativos tiene, por ultimo, una capacidad explicativa, analítica e, incluso, directiva mucho mayor que otros conceptos que se han propuesto en su lugar, pues describe mejor que ellos el fenómeno al que alude, explica adecuadamente el fundamento de que los actos hayan de ser respetados hasta que se declare autoritativamente su invalidez y posee una indudable función directiva porque, como se ha visto, ofrece pautas de comportamiento que guían y justifican la actuación de los destinatarios del acto y de la propia Administración, de modo que tiene una clara utilidad en la construcción de una teoría del acto administrativo.

\section{BIBLIOGRAFÍA CITADA}

AGUILÓ REGLA, J. (2006): "Presunciones, verdad y normas procesales", en Isegoría, núm. 35, págs. 9-31. DOI: https://doi.org/10.3989/isegoria.2006.i35.27.

AGUILÓ REGLA, J. (2018): "Las presunciones en el Derecho”, en Anuario de Filosofía del Derecho, núm. 34, págs. 201-227.

ALARCÓN SOTOMAYOR, L. (2007): El procedimiento administrativo sancionador y los derechos fundamentales. Madrid: Civitas.

ATIENZA RODRÍGUEZ, M.; RUIZ MANERO J. (2001): "La dimensión institucional del Derecho y la justificación jurídica”, en Doxa. Cuadernos de Filosofía del Derecho, núm. 24, págs. 115-130. DOI: https://doi.org/10.14198/ DOXA2001.24.05.

ATIENZA RODRÍGUEZ, M.; RUIZ MANERO, J. (2003): "Seis acotaciones para una teoría de la validez jurídica", en Doxa. Cuadernos de Filosofía del Derecho, núm. 26, págs. 719-735. DOI: https://doi.org/10.14198/ DOXA2003.26.28.

ATIENZA RODRÍGUEZ, M.; RUIZ MANERO, J. (2007): Las piezas del derecho. Teoría de los enunciados jurídicos. Barcelona: Ariel. 4. ${ }^{\mathrm{a}}$ ed.

BACA ONETO, V. S. (2006): La invalidez de los contratos. Cizur Menor: Thomson Civitas.

BARCELONA LLOP, J. (2017): "La ejecución forzosa de los actos administrativos: régimen general. La prohibición de acciones posesorias", en GAMERO CASADO, E. (dir.): Tratado de Procedimiento Administrativo Común y Régimen Jurídico Básico del Sector Público, tomo II, págs. 2.207-2.275. Valencia: Tirant Lo Blanch.

BELADIEZ ROJO, M. (1994a): Validez y eficacia de los actos administrativos. Madrid: Marcial Pons.

BELADIEZ ROJO, M. (1994b): "La nulidad y la anulabilidad. Su alcance y significación”, en Revista de Administración Pública (RAP), núm. 133, págs. 155-187.

BENTHAM, J. (1981): Tratado de legislación civil y penal. Madrid: Editorial Nacional.

BLANQUER CRIADO, D. (2014): "Disgresiones sobre la invalidez de los actos administrativos", en SORIANO GARCÍA, J. E. (dir.): Por el Derecho y la libertad. Libro homenaje al profesor Juan Alfonso Santamaría Pastor, vol. 2, Garantías del ciudadano en el régimen administrativo, págs. 1.275-1.326. Madrid: lustel.

BOCANEGRA SIERRA, R. (2011): "La distinción entre la eficacia interna y la eficacia externa de los actos administrativos", Revista Española de Derecho Administrativo (REDA), núm. 152, págs. 769-786.

BOCANEGRA SIERRA, R. (2012): Lecciones sobre el acto administrativo. Cizur Menor: Civitas Thomson Reuters.

CANO CAMPOS, T. (2004): La invalidez sobrevenida de los actos administrativos. Cizur Menor: Thomson Civitas.

CANO CAMPOS, T. (2008): Presunciones y valoración legal de la prueba en el Derecho administrativo sancionador. Cizur Menor: Civitas.

CANO CAMPOS, T. (2017): "El laberinto de la invalidez: algunas pistas para no perderse", en InDret: Revista para el Análisis del Derecho, núm. 4, págs. 1-53. URL: https://www.raco.cat/index.php/InDret/article/view/332579/423358.

CANO CAMPOS, T. (2018): "Consideraciones generales sobre la invalidez en el Derecho Administrativo", en Documentación Administrativa. Nueva Época, núm. 5, págs. 7-26, enero-diciembre 2018. DOI: https://doi. org/10.24965/da.v0i5.10605.

CAPELLA, J. R. (1999): Elementos del análisis jurídico. Madrid: Trotta.

CARRIÓ, G. R. (1990): Notas sobre Derecho y lenguaje. Buenos Aires: Abeledo-Perrot.

CASSESE, S. (1995): Le basi del diritto amministrativo. Torino: Garanti. 3. ${ }^{a}$ ed.

CHINCHILLA MARÍN, C. (1993): "Nulidad y anulabilidad", en LEGUINA VILLA, J.; SÁNCHEZ MORÓN, M. (dirs.): La nueva Ley de Régimen Jurídico de las Administraciones Públicas y del Procedimiento Administrativo Común, págs. 192-213. Madrid: Tecnos.

COSCUllUela MONTANER, L. (2019): Manual de Derecho Administrativo. Cizur Menor: Civitas Thomson Reuters. 30. ${ }^{\mathrm{a}}$ ed. 
DE LA OLIVA SANTOS, A.; DIEZ-PICAZO GIMÉNEZ, I. (2004): Derecho Procesal Civil. El proceso de declaración. Madrid: Ceura. 3. ${ }^{a}$ ed.

DE OTTO PARDO, I. (1987): Derecho Constitucional. Sistema de fuentes. Barcelona: Ariel.

DELGADO ECHEVERRÍA, J. (2019): Validez de normas y de actos jurídicos. Estudios de Teoría General desde el Derecho Privado. Madrid: Marcial Pons.

DÍEZ SASTRE, S. (2018): La formación de conceptos en el Derecho Público. Un estudio de metodología académica: definición, funciones y criterios de formación de los conceptos jurídicos. Madrid: Marcial Pons.

DOMÉNECH PASCUAL, G. (2002): La invalidez de los reglamentos. Valencia: Tirant Lo Blanch.

DOMÉNECH PASCUAL, G. (2010): "El principio de presunción de validez", en SANTAMARÍA PASTOR, J. A. (dir.): Los principios jurídicos del Derecho Administrativo, págs. 1.031-1.060. Madrid: La Ley.

ESTEVE PARDO, J. (2016): Lecciones de Derecho Administrativo. Madrid: Marcial Pons. 6. ${ }^{a}$ ed.

FERNÁNDEZ FARRERES, G. (2018): Sistema de Derecho Administrativo, tomo I. Cizur Menor: Civitas ThomsonReuters. 4. ${ }^{\mathrm{a}}$ ed.

FERRERES COMELLA, V. (2007): Justicia constitucional y democracia. Madrid: CEPC. $2 .^{\mathrm{a}}$ ed.

FERRAJOLI, F. (2000): Derecho y razón. Teoría del garantismo penal. Madrid: Trotta.

FERRAJOLI, L. (2011): Principia luris. Teoría del Derecho y de la Democracia , vol. 1. Teoría del Derecho. Madrid: Trotta.

GALLEGO ANABITARTE, A. y MENÉNDEZ REXACH, A. (2001): Acto y procedimiento administrativo. Madrid: Marcial Pons.

GAMA LEYVA, R. (2019): Las presunciones en el Derecho. Entre la perplejidad y la fascinación de los juristas. Valencia: Tirant Lo Blanch.

GARCÍA DE ENTERRÍA, E. (1985): La Constitución como norma y el Tribunal Constitucional. Madrid: Civitas. 3. ${ }^{a}$ ed.

GARCÍA DE ENTERRÍA, E. y FERNÁNDEZ RODRÍGUEZ, T. R. (2017): Curso de Derecho Administrativo, vol. I. Cizur Menor: Civitas Thomson Reuters. 18. ${ }^{a}$ ed.

GARCÍA LUENGO, J. (2002): La nulidad de pleno derecho de los actos administrativos. Madrid: Civitas.

GARCÍA-TREVIJANO FOS, J. A. (1991): Los actos administrativos. Madrid: Civitas.

GARRIDO FALLA, F. (1994): Tratado de Derecho Administrativo, tomo I. Madrid: Tecnos. 12. ${ }^{a}$ ed.

GASCÓN ABELLÁN, M. (2010): Los hechos en el Derecho. Madrid: Marcial Pons. 3. ${ }^{a}$ ed.

GONZÁLEZ LAGIER, G. (2015): "Hechos y acciones en el Derecho", en GONZÁLEZ LAGIER, D. (coord.): Conceptos básicos del Derecho, págs. 64-80. Madrid: Marcial Pons.

GONZÁLEZ NAVARRO, F. (2005): "Silencio administrativo", en MUÑOZ MACHADO, S. (dir.): Diccionario de Derecho Administrativo, tomo II. Madrid: lustel.

GUASTINI, R. (1999): Distinguiendo. Estudios de teoría y metateoría del Derecho (traducción de FERRER I BELTRÁN, J.). Barcelona: Gedisa.

GUASTINI, R. (2010): Le fonti del Diritto. Fondamenti teorici. Milano: Giuffrè.

GUASTINI, R. (2016): La sintaxis del Derecho. Madrid: Marcial Pons.

HART, H. L. A. (1997): "Mandatos y razones jurídicas dotadas de autoridad", en Isonomía: Revista de teoría y filosofía del derecho, núm. 6, págs. 83-105.

HERNÁNDEZ MARÍN, R. (1998): Introducción a la teoría de la norma jurídica. Barcelona: Marcial Pons.

KELSEN, H. (2011): "La garantía jurisdiccional de la Constitución (la Justicia Constitucional)", en Anuario Iberoamericano de Justicia Constitucional, núm. 15, págs. 249-300.

LARENZ, K. (1994): Metodología de la Ciencia del Derecho (traducción de RODRíGUEZ MOLINERO, M.). Barcelona: Ariel.

LETELIER WARTENBERG, R. (2011): Nulidad y restablecimiento en procesos contra normas. Cizur Menor: Civitas Thomson Reuters.

MARÍN-BARNUEVO FABO, D. (1996): Presunciones y técnicas presuntivas en Derecho Tributario. Madrid: McGrawHill.

MARÍN-BARNUEVO FABO, D. (2018): "Presunciones legales, disposiciones supletorias y verdades interinas. La presunción de validez de los actos administrativos", en VAQUER CABALLERÍA, M.; MORENO MOLINA, A. M.; DESCALZO GONZÁLEZ, A. (coords.): Estudios de Derecho público en homenaje a Luciano Parejo Alfonso, tomo II, págs. 1.273-1.301. Valencia: Tirant Lo Blanch.

MAURER, H. (2011): Derecho Administrativo. Parte general (traducción coordinada por DOMÉNECH, G.). Madrid: Marcial Pons.

MENDONCA, D. (1998): "Presunciones", en Doxa. Cuadernos de Filosofía del Derecho, núm. 21, págs. 83-98. DOI: https://doi.org/10.14198/DOXA1998.21.1.05.

MENDONCA, D. (2000): Las claves del Derecho. Barcelona: Gedisa.

MENÉNDEZ GARCÍA, P. (2019): "La invalidez de los actos administrativos", en MENÉNDEZ, P.; EZQUERRA, A. (dirs.): Lecciones de Derecho Administrativo. Cizur Menor: Civitas Thomson Reuters.

MONTERO AROCA, J. (2007): La prueba en el proceso civil. Cizur Menor: Thomson Civitas. 5. ${ }^{\text {a ed. }}$

MUÑOZ MACHADO, S. (2017): Tratado de Derecho Administrativo y Derecho Público General, tomo XII. Actos administrativos y sanciones administrativas. Madrid: Boletín Oficial del Estado (BOE). 2. ${ }^{a}$ ed. 
NIETO GARCÍA, A. (1994): "Estudio preliminar", en BELADIEZ ROJO, M.: Validez y eficacia de los actos administrativos, págs. 9-31. Madrid: Marcial Pons.

PARADA VÁZQUEZ, R. (2017): Derecho Administrativo II. Régimen jurídico de la actividad administrativa. Madrid: Dykinson.

PAREJO ALFONSO, L. (2015): "Algunas reflexiones sobre la vigencia de la noción de acto administrativo en el Derecho Administrativo español”, en REBOLLO PUIG, M.; LÓPEZ BENÍTEZ, M.; CARBONELL PORRAS, E. (coords.): Régimen jurídico básico de las Administraciones Públicas. Libro homenaje al profesor Luis Cosculluela, págs. 471-502. Madrid: lustel.

PAREJO ALFONSO, L. (2016): Lecciones de Derecho Administrativo. Valencia: Tirant Lo Blanch. 8. ${ }^{a}$ ed.

PAREJO ALFONSO, L. (2020): "La actuación administrativa a caballo de la división entre normación y simple ejecución y el caso de la planificación y el plan", en Revista de Derecho Público: Teoría y Método, núm. 1, págs. 7-40. DOI: https://doi.org/10.37417/RPD/vol_1_2020_25.

PAQUAU LIAÑO, M. (2007): "La acción de nulidad sí prescribe”, en DELGADO ECHEVERRÍA, J. (coord.): Las nulidades de los contratos: un sistema en evolución, págs. 225-246. Cizur Menor: Thomson Aranzadi.

PEÑA GONZALO, L.; AUSÍN DÍEZ, T. (2001): "La inferencia de los hechos presuntos en la argumentación probatoria", en Anuario de Filosofía del Derecho, núm. XVIII, págs. 95-125.

PÉREZ LLEDÓ, J. A. (2015): "Normas constitutivas: reglas que confieren poderes, reglas puramente constitutivas. Las definiciones", en GONZÁLEZ LAGIER, D. (coord.): Conceptos básicos del Derecho, págs. 27-45. Madrid: Marcial Pons.

PRIETO SANCHÍS, L. (2005): Apuntes de Teoría del Derecho. Madrid: Trotta.

RAMIA, J. (2017): "La noción de presunción más allá del Derecho", en Revista de Humanidades, núm. 32, págs. 125138. DOI: $h$ ttps://doi.org/10.5944/rdh.32.2017.18637.

REBOLLO PUIG, M. (2005): “La presunción de validez”, en Revista Española de Derecho Administrativo (REDA), núm. 128, págs. 587-638.

REBOLLO PUIG, M. (2018): "La invalidez del acto administrativo", en REBOLLO PUIG, M.; VERA JURADO, D. J. (dirs.): Derecho Administrativo, tomo II, págs. 101-121. Madrid: Tecnos. 3. ${ }^{a}$ ed.

REBOLLO PUIG, M. (2019): "Relaciones entre la Administración y los Tribunales. La autotutela administrativa", en REBOlLO PUIG, M.; VERA JURADO, D. J. (dirs.): Derecho Administrativo, tomo I, págs. 179-202. Madrid: Tecnos. 4. ${ }^{\mathrm{a}}$ ed.

RÓDENAS CALATAYUD, A. (2009): "Los enredos de la validez: tres distinciones para no perderse", en Teoría del Derecho. Revista de pensamiento jurídico, núm. 6, págs. 177-188.

RÓDENAS CALATAYUD, A. (2019): "Seguridad jurídica y principios institucionales", en el Congreso: Estado de Derecho y participación política. Homenaje a Jorge Malem. Celebrado en Tossa de Mar (Gerona) el 17-18 octubre 2019. Congreso organizado conjuntamente entre Philosophy of Law de la Universidad Pompeu Fabra y la Cátedra de Cultura Jurídica de la Universitat de Girona. URL: https://www.youtube.com/watch?v=zvivL9OK8fA.

ROSENBERG, L. (2002): La carga de la prueba. Montevideo (Uruguay): BdF. 2. a ed.

SÁNCHEZ MORÓN, M. (2020): Derecho Administrativo. Parte general. Madrid: Tecnos. 16. a ed.

SANTAMARÍA PASTOR, J. A. (1975): La nulidad de pleno derecho de los actos administrativos. Contribución a una teoría de la ineficacia en el Derecho Público. Madrid: IEA. 2. a ed.

SANTAMARÍA PASTOR, J. A. (2018): Principios de Derecho Administrativo II. Madrid: Iustel. 5. ${ }^{\text {a }}$ ed.

SCHAUER, F. (2013): Pensar como un abogado. Una nueva introducción al razonamiento jurídico. Madrid: Marcial Pons.

SERRA DOMÍNGUEZ, M. (1981): "De las presunciones", en ALBALADEJO, M. (dir.): Comentarios al Código Civil y compilaciones forales, tomo XVI, vol. 2. Madrid: Edersa.

TARUFFO, M. (2008): La prueba. Madrid: Marcial Pons.

TRAYTER JIMÉNEZ, J. M. (2019): Derecho Administrativo. Parte General. Barcelona: Atelier. 4. a ed.

VELASCO CABALLERO, F. (1996): Las cláusulas accesorias del acto administrativo. Tecnos: Madrid.

VELASCO CABALLERO, F. (2017): “El acto administrativo: concepto, clases y contenido”, en GAMERO CASADO, E. (dir.): Tratado de Procedimiento Administrativo Común y Régimen Jurídico Básico del Sector Público, tomo II, págs. 1.757-1.799. Valencia: Tirant Lo Blanch.

VILLAR PALASí, J. L. (2001): Técnicas remotas del Derecho Administrativo. Madrid: Instituto Nacional de Administración Pública (INAP).

VILLAR PALASÍ, J. L.; VILLAR EZCURRA, J. L. (1999): Principios de Derecho Administrativo, tomo II. Madrid: UCM. VON IHERING, R. (1997): El espiritu del Derecho Romano. Barcelona: Marcial Pons.

XIOL RIOS, J. A. (2013): "Artículo 57. Efectos", en SÁNCHEZ MORÓN, M.; MAURANDI GUILLÉN, N. (dirs.): Comentarios a la Ley 30/1992, págs. 405-424. Valladolid: Lex Nova. 